\title{
Mid-late Holocene environmental and cultural dynamics at the south-west tip of Europe (Doñana National Park, SW Iberia, Spain)
}

José Antonio López-Sáez ${ }^{\mathrm{a}, *}$, Sebastián Pérez-Díaz ${ }^{\mathrm{a}}$, Antonio Rodríguez-Ramírez ${ }^{\mathrm{b}}$, Antonio BlancoGonzález ${ }^{\mathrm{c}}$, Juan J.R. Villarías-Robles ${ }^{\mathrm{d}}$, Reyes Luelmo-Lautenschlaeger ${ }^{\mathrm{a}}$, Gonzalo Jiménez-Moreno ${ }^{\mathrm{e}}$, Sebastián Celestino-Pérez ${ }^{\mathrm{f}}$, Enrique Cerrillo-Cuenca ${ }^{\mathrm{f}}$, José N. Pérez-Asensiog ${ }^{\mathrm{g}}$, Ángel León ${ }^{\mathrm{h}}$

${ }^{a}$ G.I. Arqueobiología, Instituto de Historia (CCHS), C.S.I.C., Albasanz 26-28, 28037 Madrid, Spain

${ }^{b}$ Departamento de Geología, Universidad de Huelva, Avenida de las Fuerzas Armadas s/n, 21007 Huelva, Spain

${ }^{c}$ GIR PREHUSAL, Universidad de Salamanca, Cervantes s/n, 3700 Salamanca, Spain

${ }^{d}$ Instituto de Lengua, Literatura y Antropología (CCHS), C.S.I.C., Albasanz 26-28, 28037 Madrid, Spain

${ }^{e}$ Departamento de Estratigrafia y Paleontología, Facultad de Ciencias, Universidad de Granada, 18071 Granada, Spain

${ }^{f}$ Instituto de Arqueología de Mérida, C.S.I.C., Plaza de España 15, 06800 Mérida, Spain

${ }^{g}$ GRC Geociències Marines, Departament de Dinàmica de la Terra i de l'Oceà, Facultat de Ciències de la Terra, Universitat de Barcelona, Martí i Franques s/n, 08028 Barcelona, Spain

${ }^{\text {h}}$ Fundación del Hogar del Empleado (FUHEM), Colegio Lourdes, San Roberto 8, 28011 Madrid, Spain

\begin{abstract}
A multi-proxy palaeoenvironmental study (pollen, non-pollen palynomorphs, charcoal particles, mollusk macrofauna) of coastal marshland in Doñana National Park (southwestern Iberian Peninsula) was undertaken to trace environmental change, human activities related to woodland clearance, and past land-use during the mid-late Holocene ( 5000-2800 cal BP). The results of this study are combined with archaeological data from the Copper and Bronze Ages and are subsequently compared with those of similar research carried out at the south-westernmost part of Europe with the aim of discerning regional differences or similarities. Our research has allowed us to recognize climate changes and four extreme wave events in the Guadalquivir paleoestuary, which might have contributed to both the cultural change that is observed in the archaeological record at the end of the Chalcolithic and the subsequent population decline during much of the Bronze Age.
\end{abstract}

Keywords: Pollen analysis, Marshland ecosystems, Anthropization, Climate change, Extreme wave events, Holocene, Southwest Iberia

\footnotetext{
* Corresponding author. Tel.: +34 916022477 ; fax: +34 916022971

E-mail addresses: joseantonio.lopez@cchs.csic.es (J.A. López-Sáez), sebastian.perez@cchs.csic.es (S. Pérez-Díaz), arodri@uhu.es (A. Rodríguez-Ramírez), A. Blanco-González (ablancoglez@usal.es), juanjose.villarias@cchs.csic.es (J.J.R. Villarías-Robles), reyes.luelmo@cchs.csic.es (R. Luelmo-Lautenschlaeger), gonzaloj@ugr.es (G. JiménezMoreno), scelestino@iam.csic.es (S. Celestino-Pérez), enrique.cerrillocuenca@gmail.com (E. Cerrillo-Cuenca), jn.perezasensio@ub.edu (J.N. Pérez-Asensio), angelzah@hotmail.com (Á. León)
} 


\section{Introduction}

During the Upper Pleistocene and the Holocene, the south-western extreme of Europe is a territory of major archaeological and anthropological interest due to its border position at the crossroads between Europe and Africa and between the Atlantic Ocean and the Mediterranean Sea (López-García and López-Sáez, 1994a, 1994b; Pérez-Díaz et al., 2017). In the southwest of the Iberian Peninsula it has been documented the earliest known use of marine resources was by Neanderthals $~ 150$ kyr ago (Cortés-Sánchez et al., 2011) and was a crucial reservoir of biodiversity during the Upper Pleistocene and early Holocene (Carrión et al., 2008; Cortés-Sánchez et al., 2008). Southwest Iberia is also key to understanding the neolithization process in the Iberian Peninsula; evidence of Neolithic settlement is present from at least $7500 \mathrm{cal}$ BP, when an agricultural and food producing economy quickly replaced the coastal economies of the Mesolithic populations after the 8200 cal BP abrupt climatic event (López-Sáez et al., 2011; Cortés-Sánchez et al., 2012). Southwest Iberia is a unique area for the study of the funerary record and demography from the Mesolithic to the Copper Age (Díaz-Zorita et al., 2012), when some highly-elaborate tombs, such as Montelirio (Seville), feature ceremonial and rich burial goods unparalleled in Chalcolithic Europe (Fernández-Flores et al., 2016). Importantly, this region exhibits sharp cultural disruptions at the time of the $4200 \mathrm{cal}$ BP climatic event and is, therefore, crucial for tracking plausible population movements between the SW and the SE of the Iberian Peninsula (Lillios et al., 2016; Blanco-González et al., 2018). Finally, the timing and forms of interaction between local Late Bronze Age and Early Iron Age societies and the expansion of Mycenaean, Phoenician, and Greek influence, as evidenced by artefacts, are the subject of intense debate (López-Sáez et al., 2002b; Celestino-Pérez et al., 2008).

Within Southwest Iberia (Fig. 1), Doñana National Park (DNP) is one of the largest in Spain, the landscape formed as a result of a long and complex geological evolution ( 6 Myr) and anthropogenic history (Celestino-Pérez et al., 2016). The area encompasses a large system of rivers, marshes, dunes, and beaches associated with coastal dynamics at the mouth of the Guadalquivir River. The archaeological literature regarding the formation of this landscape in the course of the Holocene is still under the influence of an uniformitarian model that Shulten $(1945)$ and Gavala $(1927,1936)$ proposed in the first half of the $20^{\text {th }}$ century, before the scientific impact of Plate Tectonics Theory. According to this model, the maximum transgression of the Atlantic Ocean during the Holocene opened up a wide estuary that extended as far inland as Coria del Río, some $15 \mathrm{~km}$ south of Seville. Thereafter, estuarine and riverine sedimentation began to infill the feature, leading to the development of a major delta and the progradation, of coastal barriers. Behind these barriers, a large inland lake developed, the Lacus Ligustinus mentioned by Rufus Festus Avienus in the $4^{\text {th }}$ century AD (Rodríguez-Ramírez et al., 2016). Eventually, the lake was infilled, turning the landscape into a series of marshes and lagoons that anyone visiting the DNP today would recognize.

Elswehere with in the DNP, large tracts of the former estuary have been reclaimed by constructing flood levees and undertaking large-scale agricultural projects. Consequently, it was not until this process of extensive infilling reached a certain level, not before the Middle Ages, that the area could have carried a 
significant human population. Later versions of such an uniformitarian view are, for instance, those of Menanteau (1981), Arteaga and Roos (1995), and Escacena (2001, 2014).

However, recent geological, archaeological, and paleoenvironmetal research (Rodríguez-Ramirez et al., 2014, 2015; Jiménez-Moreno et al., 2015), including the research reported in this paper, point instead to a far more complex evolution. In this new model, geomorphological developments in the Guadalquivir paleoestuary in the Holocene, such as the formation of rivers, marshes, dunes, and beaches have been the result of complex interactions between natural processes (climate fluctuations, fluvial and coastal dynamics, and neotectonic movements) and human activities. By the end of the $5^{\text {th }}$ millennium cal BP, for instance, much of the original paleoestuary had turned into marshland by river sedimentation into the paleoestuary, reducing it to a relatively small brackish lagoon; an extreme wave event (EWE) occurring $~ 4200$ cal BP led to erosion and reversed this process, ushering in a new cycle of infilling in the paleoestuary (RodríguezRamírez et al., 2015). Because of this long, complex history of natural and human evolution, DNP has been characterized as a coupled socio-ecological system covering four major ecosystem types: marshland, dunes, coastal and estuar (Ojeda, 1990; Gómez-Baggethum et al., 2010, 2012; Palomo et al., 2014). This socioecosystem depends on freshwater flows to sustain biodiversity and agriculture, making it extremely vulnerable to human or climate-induced changes in freshwater availability (Fernández et al., 2010; MartínLópez et al., 2011). DNP is recognized as one of the most emblematic natural wetlands in Europe (Fernández-Delgado, 2006; Fernández et al., 2010). Its cultural and ecological importance is recognized through its declaration as a Ramsar site, a UNESCO World Heritage Site, and as a Biosphere Reserve. Its relevance is also acknowledged through different conservation strategies covering about $1080 \mathrm{~km}^{2}$, including a Natural Park as well as the National Park (García-Novo and Marín-Cabrera, 2006). Given the uniqueness of these environmental conditions within Southwest Iberia, and as a result of the high level of protection afforded to Doñana, Finlayson et al. (2008) consider DNP as one of the few remaining zones in Iberia that can be used as witness to the habitats and landscapes of the last Neanderthal populations. Futhermore, although Southwest Iberia is classified as a low-probability tsunamigenic area, at least sixteen EWEs, tsunamis and/or severe coastal storms have been identified so far between 7000 cal BP and AD 1900. Five to seven of them are recorded as palaeotsunamis even though the palaeoenvironmental consequences of these events are poorly known (Ruiz et al., 2010; Lario et al., 2010, 2011; Morales et al., 2011; RodríguezRamírez et al., 2015).

Since 2005, an integrated research programme involving geologists, palaeoenvironmentalists, archaeologists, historians, and anthropologists has been undertaken in DNP, with the aim of reconstructing the long-term landscape development and socio-ecological, cultural history of this coastal environment. Thus far, the programme has focused on understanding the complex, neotectonic- as well as climate-related geomorphological evolution of the Guadalquivir paleoestuary during the Holocene (Rodríguez-Ramírez et al., 2014) and on assessing the impact of EWEs on paleogeographical changes and human settlement in prehistoric, early historical, and Roman times (Rodríguez-Ramírez et al., 2015, 2016). The programme has also modelled the relationships between late Holocene climate variability and vegetation dynamics (Jiménez- 
Moreno et al., 2015) to provide insights into the geological, archaeological, and anthropological factors that have sustained the preservation of this singular natural space (Celestino-Pérez et al., 2016).

In this paper, we now present a record of mid-late Holocene ( 5000-2800 cal BP) landscape change based upon the analysis of pollen, non-pollen palynomorphs, and macrocharcoal sampled from a core (S1) drilled in the marsh of Hinojos (DNP). The study aims to redress the research gap concerning the relationship between vegetation dynamics, human impact, and climate variability, and to develop a complete picture of the complexity of human activities around this coastal wetland landscape.We combine our new palaeoenvironmental data with those from other studies carried out in Southwest Iberia. The specific aims of this combined analysis were to: i) identify different human activities; ii) evaluate the strategies followed during different periods; iii) describe the marshland landscape response to human disturbance on a microregional scale; and iv) establish the causal relationships between potential tsunamis and other EWEs and the development of the marshland ecosystems of the Doñana National Park.

\section{Study area}

\subsection{Geology and present-day geomorphology}

The Iberian Peninsula lies at the southwestern corner of the continental component of the Eurasian plate, right across the northern boundary of the African plate, an area also known as the Azores-Gibraltar fault zone. The present geological structure of the Gulf of Cadiz is the result of the European-African plate convergence motion, dextral strike-slip along the Azores-Gibraltar Plate Boundary (Medialdea et al., 2009). The Gulf of Cadiz includes a number of estuaries containing deltas, all of them partly enclosed by coastal barriers or spits. The largest delta is, by far, that of the Guadalquivir River, enclosed by two spits: Doñana and La Algaida (Fig. 1a). The entire area comprises one of the largest wetlands (54,720 ha) in Europe and incorporates the Doñana National Park (DNP). The park lies on the right bank of the Guadalquivir River and extends over 50,700 ha along the coastal plain of the Gulf of Cadiz (Fig. 1a); it includes four morphogenetic systems: estuarine, fluvial, littoral, and aeolian (Rodríguez-Ramírez et al., 1996). The present-day landscape is the outcome of the complex geological evolution of the lower Gualdalquivir River valley since late Miocene times, though the majority of recent change has occurred since the Last Glacial Maximum. Postglacial sea-level rise reached its maximum $\sim 6500 \mathrm{cal} \mathrm{BP}$ and caused the drowning of the area (Zazo et al., 1994); since then, the Guadalquivir estuary has been enlarged and reshaped by the formation of sandy spits after the last postglacial transgression, littoral dynamics largely controlling such development in the present landscape (Rodríguez-Ramírez et al., 1996).

The growth of littoral spit bar systems induced the creation of protected marshland areas and the formation of dune ridges systems on top of the spit bars. The marshland areas are the end product of the sedimentary infilling of the original Holocene basin / paleoestuary by the Guadalquivir river and other channel systems, a complex process that started to develop in the manner of a bird foot delta type formation 
in a low-energy environment (Rodríguez-Ramírez et al., 1996; Rodríguez-Ramírez, 1998). These marshes are fed by a main tributary (Guadalquivir River) and numerous ebb-tide channels or "caños" (Travieso, Guadiamar, Madre de la Marisma), with recent and former banks denoted by clay-rich levees as well as bioclastic and beach-morphology ridges (Carrizosa-Vetalarena, Las Nuevas, Vetalengua) (Fig. 1a). With a low gradient, features in the marshland include various landforms (levees, channels, point-bars) that have resulted from intense fluvial action and extensive sandy and shelly ridges (cheniers) resting on the clayey sediments, which have been shaped by marine processes, occasionally very violent, operating against the spit bars (Rodríguez-Ramírez et al., 1996). Prevailing winds are from the SW (Fig. 1b) and although winds from the SE and E are less common, they are important since they are commonly associated with storm events (Rodríguez-Ramírez, 1998). The sheet of aeolian sediments is composed of several generations of dunes (Fig. 1a) formed by westerly winds; some stabilized dune systems date to the Late Pleistocene (31-11.5 kyr cal BP, systems I and II), and others to the early to mid-Holocene (11-5/4 kyr cal BP, system III), while active dune systems (IV and V) have formed during the late Holocene (Rodríguez-Ramírez et al., 1996, 2005).

This study focuses on the marshland area ("marisma"), which includes the great alluvial plain and the ecosystem of greater extension of the National Park, covering an area of approximately 34,000 ha. This area, which has an average elevation of $1.35 \mathrm{~m}$ above sea level (asl), is formed by impermeable silt-clay soils (Fig. 1a). The climate of DNP is Mediterranean with an Atlantic influence, usually classified as dry sub-humid, with wet, mild winters and dry, hot summers; the annual average rainfall is $580 \mathrm{~mm}$, with high inter-annual fluctuations (Siljeström et al., 1994; Serrano et al., 2006). Although some areas are influenced by Atlantic tides in and out of the Guadalquivir River estuary, most of the marshland is free from tidal influence (Rodríguez-Ramírez et al., 1996). The marshland receives surface waters from the Guadiamar River basin and the Guadalquivir River estuary, but also from artificial water sources; the water entering these rivers and streams comes from the underlying aquifer as well as rainfall (Serrano et al., 2006). The hydrological pattern of the marshland exhibits a typical Mediterranean climate dynamic, with sudden and irregular flooding followed by long periods of confinement and dryness (Geertz-Hansen et al., 2010). The marshland follows a marked annual cycle, filling up with water in October, reaching an average depth of $20 \mathrm{~cm}$, and remaining flooded until March/April, forming an inundated surface area. Afterwards, net water losses through evapotranspiration gradually dry out the marsh. By the end of the summer, only the deepest depressions retain highly saline waters, such as shallow ponds, gullies, and some channel stretches (Geertz-Hansen et al., 2010).

\subsection{Modern vegetation}

DNP comprehends three main ecosystems (Fig. 1b): the stabilised sands, the mobile dunes, and the salt marshes (Clemente et al., 1997; García-Novo and Marín-Cabrera, 2006). The stable dune systems, which occupy almost a third of the total surface in El Abalario dune field (Fig. 1a), comprise ancient dunes that 
extend inland towards the NW limit of the marshland (Rodríguez-Ramírez et al., 1996). Their vegetation, locally known as "cotos" consists of extensive woodlands (Rivas-Martínez et al., 1980; Siljeström and Clemente, 1990). Juniperus phoenicea subsp. turbinata, J. oxycedrus subsp. macrocarpa, and Pistacia lentiscus characterize the driest and xerophytic enclaves, accompanied by the so-called "monte blanco" (scrubland made of Cistus salvifolius, C. libatonis, Osyris quadripartita, Rosmarinus officinalis, Stauracanthus genistoides, Thymus mastichina, Lavandula stoechas, Helichrysum angustifolium, Halimium commutatum, and H. halimifolium), while cork oak (Quercus suber), stone pine (Pinus pinea), Phillyrea angustifolia, and Olea europaea var. sylvestris thrive in moister areas, accompanied by the so-called "monte negro" (scrubland made of Rubus ulmifolius, Ulex minor, U. australis, and Calluna vulgaris, which, in particularly humid areas, incorporate hygrophytic species such as Erica scoparia, E. ciliaris, E. umbellata, Saccharum ravennae, and Imperata cylindrica). The most hygrophytic plants of the cork oak woodland include Arbutus unedo, Pyrus bourgeana, Myrtus communis, Smilax aspera, Rubia peregrina, and Lonicera periclymenum. Ripparian communities consist mainly of Tamarix africana, T. canariensis, Populus alba, Fraxinus angustifolia, Salix alba, and Ulmus minor. Vegetation compostion of the mobile dunes is dependent on the speed of (dune) movement and the depth of the water table, there being large areas of bare sand (Finlayson et al., 2008). The main woody species in the interdunal valleys are Pinus pinea and Corema album, while the dune crests are dominated by psammophilous communities of Ammophila arenaria, Artemisia crithmifolia, and Armeria pungens, as well as by scarce Juniperus phoenicea subsp. turbinata trees (Rivas-Martínez et al., 1980; López-Albacete, 2009).

The vegetation of the marshland (Fig. 1b) is determined by both the aforementioned seasonality and the microtopography (Rivas-Martínez et al., 1980; García-Viñas et al., 2005; López-Albacete, 2009). The lowlying zones that remain flooded for longer periods in the yearly cycle (6-8 months) are called "lucios", which constitute, with the partly-blocked fluvio-tidal channels ("caños"), the low marsh or "marisma baja" (Rodríguez-Ramírez, 1998). Helophyte swamp communities (freshwater marshes), dominated by species of Cyperaceae (Scirpus maritimus, S. lacustris, S. littoralis, Eleocharis multicaulis) and Isoetes spp., characterize the "caños" and their side areas ("quebradas"), while the "lucios" host macrophyte communities of both submerged- (Callitriche spp., Myriophyllum alterniflorum, Ruppia drepanensis) and floating aquatic macrophytes (Potamogeton spp., Hydrocharis morsus-ranae, Ranunculus subgen. Batrachium, Lemna spp.) (Díaz-Paniagua et al., 2010). Halo-nitrophilous communities (salt marshes), dominated by species of Chenopodiaceae (Arthrocnemum macrostachyum, Salicornia ramosissima, Suaeda vera), the so-called high marsh ("marisma alta"), characterize the highest elevation enclaves (1-3 m asl), known as "paciles" and "veras". "Paciles" are upper areas that have the appearance of emerged islands during heavy floods); "veras", which present a ground water seepage along the ecotone between the marshland and the "caños", are small raised areas of sandy soil that are relicts of old beaches or margins of the estuary and provide humidity to meadows and hygrophitic vegetation). This saline marsh vegetation dominates much of DNP due to the enormous extension of the saline soils (García-Viñas et al., 2005; García-Novo and Marín-Cabrera, 2006), not only in the higher areas but also during the periods in which the marshland is not flooded (April- 
October). Arthrocnemum macrostachyum is the most abundant species in the DNP marshes, thanks to its ability to take advantage of subsurface hypersaline waters during the summer, or dry season, and its ability to resist shallow flooding during the rainy season (García-Murillo et al., 2007). In the months of rain and flooding, this vegetation is gradually replaced by freshwater marsh and aquatic communities in the lower areas, because of the dilution of surface salinity and the underground rhizomes that resist the dry season (Espinar, 2004).

\section{Materials and methods}

\subsection{Geomorphology}

Aerial photographs from $1956(1: 33,000)$ and 2013 (1:10,000) were analysed to map the detailed geomorphology of landforms and sediments. The analysis was complemented by direct observations in the field. The Topographic Map of Andalusia $(1: 10,000)$ was used as a base document for geomorphological mapping and all information was integrated and analyzed within a project GIS (gvSIG).

\subsection{Coring, sampling, sedimentological analysis and radiocarbon dating}

A $1200 \mathrm{~cm}$ long core (S1, 36 $57^{\circ} 36.62^{\prime \prime} \mathrm{N} ; 6^{\circ} 23^{\prime} 8.80^{\prime}, \mathrm{W}, 1.5 \mathrm{~m}$ asl) was retrieved from the central part of the Doñana marshland (Fig. 1) in July 2016, using a rotation-drilling machine with continuous core sampling. Here we only present data for the lower $900 \mathrm{~cm}$ of the core (Fig. 2). The sediment core sections were placed in plastic tubes, protected in plastic guttering, and stored under cold conditions $\left(4{ }^{\circ} \mathrm{C}\right)$ prior to laboratory sub-sampling and analysis. The stratigraphy and lithology of the core was described in the field. Grain-size distribution was determined in the laboratory by wet sieving for the coarser fractions $(>100 \mu \mathrm{m}$ small) and by photosedimentation on a Mastersizer 2000 laser diffractometer ("Sedigraph 5100") for fractions smaller than $100 \mu \mathrm{m}$. The core was sectioned into continuous $10 \mathrm{~cm}$-thick slices for pollen analysis.

Five samples of mollusk shell were radiocarbon-dated using the AMS technique. The dating was conducted by Beta Analytic Inc. (Miami, USA) and the Accium BioSciences AMS Laboratory (Seattle, USA). The marine shells selected were those that showed a low degree of transport or no transportation and had preserved and articulated valves. The dates were calibrated using CALIB 7.1 with the Marine13 curve (Reimer et al., 2013) (Table 1). Correction of the reservoir effect followed the specific guidelines suggested by Soares and Martins (2010) regarding calibration of marine shells from the Gulf of Cadiz; they have recommended a $\Delta \mathrm{R}$ value of $100 \pm 100{ }^{14} \mathrm{C}$ yr for the age range $4400-4000{ }^{14} \mathrm{C}$ yr BP. Because a lack of sufficient data for the next two millennia preclude determining with enough confidence the most recent time boundary to which the $100 \pm 100{ }^{14} \mathrm{C}$ yr $\Delta \mathrm{R}$ value can be extended, we chose to extend it to the middle year $3000{ }^{14} \mathrm{C}$ yr BP. New data on reservoir effects are necessary to calibrate with greater precision samples from the Gulf of Cadiz (Lario et al., 2011). An age-depth model was produced by using Clam 2.2 software 
(Blaauw, 2010); the best fit was obtained after applying a smoothing spline to the available radiocarbon dates. Confidence intervals of the calibrations and the age-depth model were calculated at $95 \%(2 \sigma)$ with 1,000 iterations. According to such a model, the base of the $1200 \mathrm{~cm}$ core can be assigned to the Copper Age $(\sim 5000 \mathrm{cal} \mathrm{BP})$ and the sequence extends up to the present day. Terms and reference dates for classification into cultural periods are those of García Sanjuán and Odriozola (2012), who on the basis of accumulated ${ }^{14} \mathrm{C}$ datings for Southwest Iberia have proposed to distinguish between "The Copper Age" (to $4200 \mathrm{cal}$ BP), "The Early Bronze Age" ( 4200-3500 cal BP), and "The Late Bronze Age" ( 3500-2800 cal BP).

\subsection{Pollen analysis}

Pollen analysis was carried out on 90 sub-samples of $1 \mathrm{~cm}^{3}$ along the lower $900 \mathrm{~cm}$ of the core. The core had a particularly good resolution for the Copper and Bronze Age, $\sim 5000$ cal BP to $\sim 2800$ cal BP, providing nearly decadal resolution $(2.4 \mathrm{yr} / \mathrm{cm})$. All samples were treated chemically ( $\mathrm{HCl}, \mathrm{KOH}, \mathrm{HF})$ following the standard procedures described by Moore et al. (1991), using Thoulet solution for densimetric extraction of pollen and non-pollen microfossils (Goeury and de Beaulieu, 1979). Acetolysis, however, was not applied, in order to allow identification of any contamination by modern pollen. Palynomorphs were identified at 400x and 1000x magnification by the use of the reference collection of the Institute of History at CSIC-Madrid, as well as identification keys and photo-atlases (Sáenz, 1982; Moore et al., 1991; Reille, 1999; van Geel, 2001; Beug, 2004; Cugny et al., 2010). Cistaceae pollen types were discriminated according to Sáenz (1979); Pinus pinaster and Quercus suber pollen differentiation followed Carrión et al. (2000a, 2000b). Pollen concentration (grains $\mathrm{cm}^{-3}$ ) was estimated by adding a Lycopodium tablet to each sample (Stockmarr, 1971) and these values were divided by deposition time (year $\mathrm{cm}^{-1}$ ) to calculate pollen accumulation rate (grains $\mathrm{cm}^{-2}$ year-1). Pollen counts of up to 400 grains total land pollen (tlp) per sample were identified and counted. Pollen of aquatic or wetland plants as well as spores and non-pollen palynomorphs (NPPs) were excluded from the pollen sum. The pollen diagrams have been plotted against age, using TGview (Grimm, 2004).

\subsection{Charcoal analysis}

Charcoal debris were counted under the microscope alongside the identification of pollen and classified into two size classes (Vannière et al., 2008), namely $>125$ and $<125 \mu \mathrm{m}$, interpreted as indicating local and regional fires, respectively (Whitlock and Larsen, 2001). Charcoal accumulation rates (CHAR) were calculated by sedimentation rates $\left(\mathrm{cm}\right.$ year ${ }^{-1}$ ) and expressed in particles $\mathrm{cm}^{-2}$ year ${ }^{-1}$ (Long and Whitlock, 2002). It is noted that pre-treatment processes can damage or split original large charcoal debris into smaller pieces. Yet, since all samples were processed using the same procedure, we assume that this systematic bias was uniform across samples and therefore did not influence the indicated temporal variation of charcoal 
abundance. Previous studies comparing the sieving charcoal series versus the pollen-slide charcoal series show that both of them display a similar pattern (Carcaillet et al., 2001; Yin et al., 2016).

\subsection{Paleontology}

Macrofossil analysis from sediment samples was undertaken in order to identify mollusk species type and diversity. Furthermore, mollusk shell taphonomy was assessed. Thirty-three samples were collected from the core and prepared by washing the bulk sediment $\left(12 \mathrm{~cm}^{3}\right)$ through a $1 \mathrm{~mm}$ sieve. Bivalves and gastropods were identified to species level and then counted to study the semi-quantitative distribution of species along the studied core interval. The presence and relative abundance of other groups (such as scaphopods, barnacles, and bryozoans) were also noted.

\section{Results}

\subsection{Facies identification, core lithology and chronostratigraphy}

The lowest part of core S1 (Fig. 2), from 1200 to $970 \mathrm{~cm}(\sim 5000-4560 \mathrm{cal} \mathrm{BP})$, suggests a typical marsh estuary sequence of mostly grey-greenish (10YR6/1) clayey silts (52-55\% clay, 42-44\% silts, and 2-5\% sand). The mollusk assemblage appears to be dominated by shallow-water estuarine bivalve species from sheltered environments, including Tellina spp. and Crassostrea angulata; Cerastoderma edule - typical from lagoonal environments - and Barnea candida appeared in a minor proportion. The gastropod class is characterized by greater species diversity, though with a very low density of specimens. The species found are Nassarius reticulatus, Rissoa spp., Bittium reticulatum, Cerithium spp. and Bulla spp. In general, the mollusk macrofauna indicates minimal transportation, particularly bivalves; both valves were present, some of them even in life position (Ruiz et al., 2005b; Rodríguez-Ramírez et al., 2015). Open marine species Venus spp. - were very sparse and found scattered; they were probably transported to the study area. Relatively low sediment accumulation rates characterize this earliest part of the S1 record, with values of around $5.22 \mathrm{~mm} / \mathrm{yr}$.

In the S1 record we were able to identify a first EWE at a depth of 970-930 cm (EWE-1: 4560-4450 cal BP) from the significant amount of sand (15-20\% sand). This first sand layer (Fig. 2) consists of grey (10YR6/4) clayey silty sands (55-60\% silts, $22-30 \%$ clay). The macrofauna is characterized by a mixture of disarticulated valves, shell fragments, and whole bivalves, of a high species diversity characteristic of marine environments as well as those that are typical of the inner estuary. The bivalvia class is represented by a greater abundance of Cerastoderma edule, Tellina tenuis, Tellina spp, Crassostrea angulata, Neopycnodonte spp., Octorea edulis, Barnea candida, Spisula solida, Solen spp., Venus spp., Chlamys multistriata, Nucula nucleus, Pecten spp., Donax spp., Chamelea gallina, Anomia ephippium, Loripes lucinalis, and Tapes decussatus. Regarding the gastropod class, Nassarius reticulatus, Rissoa spp., Murex bandraris, and Bittium 
reticulatum stand out, while Calyptraea chinensis appears sporadically. Some specimens of scaphopodos, bryozoans, and crayfish remains are also present. Further up, between 930 and $860 \mathrm{~cm}$, the amount of sand in the core progressively decreases $(10 \%)$, while the amount of clay increases and silt decreases within greygreenish (10YR6/1) clayey silts (Fig. 2). In this facies $\sim 4450-4200$ cal BP the macrofauna is exactly the same as the one described for the first facies of the record, $\sim 5000-4560 \mathrm{cal}$ BP, suggesting again a closed paleoestuary with hardly any marine influence. Low sediment accumulation rates $(2.80 \mathrm{~mm} / \mathrm{yr})$ also characterize this part of the S1 record. At the top of this facies, between 900 and $860 \mathrm{~cm}$ (Fig. 2), sand levels reach a minimum $(7 \%)$, as do silts $(28 \%)$, while clays increase considerably $(65 \%)$, though the faunal composition remains the same as in the previous facies.

A second EWE is record in the lithostratigraphy $~ 4200-4000$ cal BP - between 860 and $800 \mathrm{~cm}$ (EWE-2; Fig. 2); the layer comprises grey (10YR6/4) heterometric sands (45\% sand content) within a matrix containing a relatively high percentage of sandy silts (33\%) and clay (22\%). Low sediment accumulation rates $(3.00 \mathrm{~mm} / \mathrm{yr})$ characterize this part of the $\mathrm{S} 1 \mathrm{record}$. The macrofauna includes the same abundance of mollusk species described for the first EWE event $\sim 4560-4450$ cal BP.

Later, $\sim 4000-3500 \mathrm{cal}$ BP $(800-615 \mathrm{~cm})$, the granulometry and the macrofauna are again the same prior to EWE-2, showing a matrix with high percentages of clay (70\%) and, to a lesser extent, silts (25\%), including $5 \%$ of sands (Fig. 2), and low sediment accumulation rates $(3.70 \mathrm{~mm} / \mathrm{yr}$ ).

Between 3500 and 3435 cal BP, a new EWE (EWE-3) is documented in the core by a sand layer within grey (10YR6/4) clayey silts, between 615 and $590 \mathrm{~cm}$ (35\% sand, 42\% clay, 23\% silts). The layer exhibits a fining-upward succession of sediments, its boundary with the lower formation of silty clays being slightly erosive (Fig. 2). A sediment accumulation rate of $3.80 \mathrm{~mm} / \mathrm{yr}$ characterizes this part of the $\mathrm{S} 1 \mathrm{record}$. The macrofauna is similar to that of the two previous sandy facies, mentioned above: the layer shows an increase in articulated and disarticulated bivalve shells and shell fragments within a high diversity of characteristic species from marine environments as well as others typical of the inner estuary. Later, $\sim 3435-3185$ cal BP between 590 and $500 \mathrm{~cm}$ - the sedimentary facies (Fig. 2) is characterized by a typical marsh estuary sequence of mostly grey-greenish (10YR6/1) clayey silts (43-74\% silts, 30-57\% clay, $1-2 \%$ sand), while the mollusk macrofauna appears to be dominated by the shallow brackish estuarine species described above, with relatively low sediment accumulation rates around $3.60 \mathrm{~mm} / \mathrm{yr}$.

A fourth EWE (EWE-4) is documented in the S1 record by a small accumulation of sands (5\%) within the clayey silts ( $65 \%$ silts, $30 \%$ clay) between 500 and $480 \mathrm{~cm}$ (Fig. 2), that is, $\sim 3185-3140$ cal BP. The sediment accumulation rate increased to $4.44 \mathrm{~mm} / \mathrm{yr}$. This facies includes a muddy-sandy layer overlying an erosive base that contains an accumulation of shells and shell fragments, mostly coming from marine mollusk species (although there are also estuarine species). Further up core S1 (480-300 cm; 3140-2800 cal BP), the sedimentation changes progressively into grey-ochre silty clays (10YR8/4) (27-67\% silts, 30-73\% clay, 0-3\% sand), while the accumulation rate increases to $5.29 \mathrm{~mm} / \mathrm{yr}$ (Fig. 2). This part of the core exhibits a scant macrofauna in terms of both number of individuals and number of species: within the bivalvia class, 
Scrobicularia plana, Cerastoderma edule, Tellina tenuis, and Tellina spp.; within the gastropod class, only Rissoa spp.

\subsection{Pollen, non-pollen palynomorphs and charcoal}

The results of pollen, non-pollen palynomorphs (NPPs) and charcoal analyses are displayed in Figs. 3-5. To establish the zonation of the pollen sequence, we tested several divisive and agglomerative methods with the program IBM SPSS Statistics 21. Based on the ecological meaning of the obtained zones, nine local pollen assemblage zones (LPAZ-1 to LPAZ-9) were constructed on the basis of agglomerative constrained cluster analysis of incremental sum of squares (Coniss) with square root transformed percentage data (Grimm, 1987). The number of statistically significant zones was determined by using the broken-stick model (Bennett, 1996). A total of 109 pollen, spore, and non-pollen palynomorph types were identified. The results of the identification and counting are presented as percentage diagrams (Figs. 3-4). Fig. 5 shows both microscopic and macroscopic CHARs related to selected pollen and NPP percentage curves. The terms 'local' (0-20 m), 'extra-local' (20 m-2 km), and 'regional' ( $>2 \mathrm{~km})$ used in the text refer to different pollen source areas according to Prentice (1985). The pollen proportion (Fig. 3) of Pinus pinaster $(<3 \%$ ), Pinus sylvestris/nigra (1-4\%), and deciduous Quercus $(<7 \%)$ can be attributed to long distance ('regional') transport from mountainous areas (López-Sáez et al., 2010a, 2010b, 2013, 2015). However, it should not be ruled out that some dispersed specimens of Pinus pinaster or P. nigra could be from trees that lived in the DNP area during the Holocene, since abundant macrofossils of both species have been found in Upper Pleistocene aeolian deposits exposed in the Asperillo cliff (Postigo-Mijarra et al., 2010; Morales-Molino et al., 2011), as have been wood remains from Pinus pinaster on Matalascañas beach that date from the late Holocene (Rodríguez-Ramírez et al., 2012).

Geobotanical interpretation of stone pine woodlands (Pinus pinea) in the DNP have led to controversial interpretations between those who accept the natural character of these woodlands (Costa-Tenorio et al., 1997) and those who reject it (Rivas-Martínez et al., 1980; Asensi and Díez-Garretas, 1987). This debate is still ongoing, despite a growing body of evidence from historical and palaeoecological studies that point to the native origin of these regional stone pine forests (Martínez and Montero, 2004). In Southwest Iberia, macrofossil and palynological records show the presence of stone pine for at least the last $50 \mathrm{kyr}$ (Stevenson, 1984, 1985; López-Sáez et al., 2001, 2002a; Carrión et al., 2008), suggesting the permanence of widespread coastal pine woodlands since the Upper Pleistocene. Pinus pinea type is present in the S1 pollen record from the mid-Holocene $\sim 5000$ cal BP (Fig. 3), demonstrating the natural character of stone pine woodlands in DNP; this is also in accordance with natural habitat predictions for the mid-Holocene derived from machine learning models (Benito-Garzón et al., 2007).

In reference to the grapevine (Vitis vinifera), its presence is more or less constant throughout the S1 pollen record (Fig. 3), although always sporadically and in low percentages (0-2 \%). Similar percentages of grapevine pollen have been documented in the mid-Holocene record from El Acebrón (Fig. 6) (Stevenson 
and Moore, 1988; Stevenson and Harrison, 1992), which the authors interpret as the existence of wild populations along stream corridors; however, the recurrence of pyrophilous pollen taxa such as Cistus ladanifer leads them to consider the possibility of local cultivation. This latter hypothesis is also supported by Stevenson (1985) from the documentation of exceptionally high percentages of Vitis $(>40 \%)$ in the pollen record from Las Madres (Fig. 6), which led this author to argue for the local cultivation of grapevine in the Doñana area between the Late Neolithic and the Copper Age. However, a later study of this same sequence points out the possible misidentification between Vitis and Rhamnus pollen types (Yll Aguirre et al., 2003). In short, should we assume the existence of wild populations of grapevine (Vitis vinifera subsp. sylvestris) in the DNP (Cantos et al., 2017); the data provided by the S1 pollen record (Fig. 3) probably indicate the natural existence of the species in riparian forests with Salix atrocinerea and Thelypteris palustris (RivasMartínez et al., 1980).

\section{Discussion}

\subsection{Copper Age ( 5000-4200 cal BP)}

The S1 core sediment record started $\sim 5000$ years ago (Table 1 ). The geomorphological scenario $\sim 5000$ 4200 cal BP (Rodríguez-Ramírez et al., 1996, 2014, 2015; Ruiz et al., 2005b) is a more or less closed paleoestuary with little marine influence and permanent fresh water input, partially protected along its westernmost boundary by aeolian units and to the south and southeast by the growing Donana barrier spit (Fig. 6c). By $\sim 4200 \mathrm{cal}$ BP, the extension of the paleoestuary may have been less than half of what it was at the time of the Postglacial Maximum, $\sim 6500 \mathrm{cal} \mathrm{BP,} \mathrm{making} \mathrm{it} \mathrm{a} \mathrm{brackish} \mathrm{lagoon} \mathrm{in} \mathrm{practice.} \mathrm{North} \mathrm{of} \mathrm{this}$ lagoon, the original paleoestuary had turned into marshland, the oldest marshland formed in the lower Guadalquivir river valley during the Holocene (Fig. 6c).

The aforementioned data agree with the pollen spectra of LPAZ-1 5000-4560 cal BP (Figs. 4-5), where the low marsh dominates locally (21.1-29.7\%). The dominant vegetation was Cyperaceae (15.6-22.6\%) grasslands, with species able to withstand certain seasonal changes in salinity and relatively brackish waters, such as Scirpus maritimus, S. littoralis, and Alisma plantago-aquatica (Alismataceae, 1.1-2.6\%) among the helophytes, which would thrive in silty clay soils with some sand content (Rivas-Martínez et al., 1980). The continued presence of cf. Persiciospora (HdV-124) is related to helophyte marsh with eu- to mesotrophic conditions (Pals et al., 1980). Aquatic submerged macrophytes such as Ruppia (2.5-4.1\%) and Zannichellia developed in brackish areas of deeper water, while on the surface there were dense floating aquatic macrophytes lawns (Lemna 1.6-4.5\%, ) capable of living in relatively saline waters. High marsh plants (9.1$12.7 \%$ ) would populate the edges of the lagoon, being composed mainly by Chenopodiaceae, Artemisia, Armeria/Limonium, and Frankenia. In addition, in lower brackish areas, or in freshwater pools fed by fluvial inputs, communities of submerged macrophytes $(\sim 2 \%)$ dominated by Callitriche and Myriophyllum alterniflorum, accompanied by other pollen taxa of floating macrophytes (2-3\%; Hydrocharidaceae, 
Nymphaea alba, Nuphar luteum, Potamogetonaceae, Ranunculus, Riccia) developed. High values of Isoetes $(8-18 \%)$ - a fern that lives in seasonally flooded soils - are noteworthy in this pollen zone, pointing out the prevalence of shallow waterlogged environments in the proximity of the core site (Valdés et al., 2007). The constant presence, though in low values, of dinoflagellata cysts $(<3 \%)$ can be explained by a certain marine influence inside the paleoestuary. In short, $\sim 5000-4560$ cal BP the marsh would comprise a mosaic of diverse plant communities, determined by salinity and microtopography.

From a palynological point of view, the lithostratigraphic and macrofaunal record of EWE-1 4560-4450 cal BP corresponds to pollen zone LPAZ-2 (Fig. 4), which is characterized by the appearance of Foraminiferae (2.6-4\%), the increase of Dinoflagellata (7-8\%), Cyperaceae (25\%), and Ruppia (4-6\%) and a significant drop $(<1 \%)$ of both freshwater floating and submerged macrophytes (Fig. 5). High values of Glomus (5-7\%) and Pseudoschizaea circula (4-5\%) can be correlated with erosive processes on land derived from EWE-1, whereas percentage increases $(\sim 4 \%)$ of both HdV-222 and HdV-229 are related to the contribution of sand in the sedimentary deposit (van Geel et al., 1989; López-Sáez et al., 1998). All of these data suggest the existence of a paleoestuary still confined $\sim 4560-4450$ cal BP, but with greater marine influence. It is the first time that an EWE has been detected in this chronological range in the DNP, although the record could also be probably related to the storm surge with spit barrier breaching described by Lario et al. $(1995,2010,2011)$ and Rodríguez-Ramírez et al. (2015) for $~ 4500-4200$ cal BP in the Guadalquivir marshland. Probably, EWE-1 would have had no more than a local effect - the sediment accumulation rate ( $3.63 \mathrm{~mm} / \mathrm{yr}$ ) being even lower than in the preceding phase - and, therefore, would not have affected the prehistoric settlement of the marshlands. In fact, the S1 pollen record (Figs. 4-5) shows the continuous presence of cereal pollen with high values (1-2.5\%) as well as notable pastoral pressure (coprophilous fungi $18-20 \%) \sim 4560-4450$ cal BP; furthermore, the relative stability of both "monte negro" and "monte blanco" woodland pollen assemblages $\sim 5000-4200 \mathrm{cal}$ BP is not disrupted $\sim 4560-4450$ cal BP (Fig. 5).

Between $~ 4450$ and 4200 cal BP (LPAZ-3) the vegetation is very similar to that described in LPAZ-1 (Figs. 3-4). Cyperaceae (27\%) and Isoetes (19\%), as well as many other typical low marsh or freshwater pollen taxa (Alismataceae, Elatine, Hypericum, Lotus, Lythrum, Ludwigia palustris, Phragmites, Typha angustifolia, and T. latifolia), increase within helophytes, while Callitriche (3.7\%) and Myriophyllum alterniflorum (2.5\%) also increase within freshwater-submerged macrophytes at the top of LPAZ-3, 43604200 cal BP. Freshwater floating macrophyte taxa are also well represented, particularly Potamotegonaceae (3\%), while Lemna disappears and Ruppia slightly decreases (Figs. 4-5). These data can be related to a humid phase described for the western Mediterranean $~ 4350-4150$ cal BP, during which rainfall increased considerably (Magny, 2004; Magny et al., 2006; López-Sáez et al., 2017). In the case of the DNP, such rainfall increase would mean a greater contribution of fresh water to the marshland, increasing the low marsh (40\%) and decreasing the high marsh (7\%), producing also an increase of algal populations (Botryococcus, Pediastrum, Zygnemataceae) and other NPPs (HdV-18, HdV-181, Gyratrix hermaphroditus); these taxa are signs of meso-eutrophic moist environments (López-Sáez et al., 1998; van Geel and Aptroot, 2006). This 
humid phase is also well represented in the S1 pollen record by the development of the more hygrophytic "monte negro" facies (Fig. 5).

During the mid-Holocene ( 5000-4200 cal BP; LPAZ-1 to LPAZ-3), extra-local DNP forest landscapes, according to data from S1 record, are characterised by the presence of poorly-developed "monte negro" woodlands, with Quercus suber (4-15\%), Olea europaea, and Pinus pinea (7-22\%) as the main taxa, probably occupying the stable dunes of El Abalario that are closest to the lagoon (Fig. 6c). Shrubs were abundant, with Calluna vulgaris, Arbutus unedo, Erica, Ulex/Cytisus, Myrtus, Rubus, Smilax aspera, Rubia peregrina, Lonicera, and Phillyrea being the most important taxa from "monte negro" shrubland, and Cistus, Ephedra fragilis, Daphne gnidium, Rhamnus lycioides, Asparagus, Osyris, Juniperus, Pistacia lentiscus, Halimium, and Lamiaceae from "monte blanco" shrubland (Figs. 3 and 5). Pteridium aquilinum (1-5\%) and Ophioglossum are two ferns that are also characteristic of "monte negro" shrubland (Fig. 3). Quercus suber percentages are fairly low 5000-4200 cal BP (Fig. 3), which indicate a "dehesa-type" landscape (LópezSáez et al., 2010a). LPAZ-1 to LPAZ-3 are also characterized by significant frequencies of anthropogenic nitrophilous herbs (Aster, Boraginaceae undiff., Cardueae, Cichorioideae, Heliotropium, Malva sylvestris, Rumex acetosa, R. acetosella) and anthropozoogenous types like Plantago lanceolata (1-4\%), P. major/media $(\sim 1 \%)$, and Urtica dioica $(1.5-4 \%)$, as well as by the continuous presence of coprophilous fungi such as Chaetomium, Sordaria, Cercophora, Sporormiella, Coniochaeta, and Podospora (Figs. 4-5); all of which suggests seasonal grazing activities and significant human pressures (Galiano and Cabezudo, 1976; Cabezudo, 1979; Behre, 1981; López-Sáez and López-Merino, 2007), associated with a large settlement $\sim 5000-4200$ cal BP at the DNP (Fig. 6c).

Cerealia (0.5-2.6\%) show a continuous record 5000-4200 cal BP (Figs. 4-5), revealing extra-local agriculture (López-Sáez and López-Merino, 2005). On the eastern paleocliffs and plateaux bordering the coastal lagoon (Fig. 6c) where the soils are more fertile than in the El Albalario dune zone, to the west (Bejarano, 1997; García-Rivero, 2004), numerous Chalcolithic sites have been identified (Arteaga and Roos, 1992). However, considering the geographical position of S1 (Fig. 6c) and the relatively high values (> 2\%) of cereal pollen $\sim 5000-4950,4885,4815,4670$, and 4535 cal BP (Fig. 4), it is likely that agriculture was practiced also in the sandy western area of the Doñana marshland during this time, especially in those areas of the floodplain where the concentration of surface salt was low. In parallel, the continuous presence 5000-4200 cal BP of Cyanobacteria Anabaena (2-4\%) and Aphanizomenon (0.5-2.5\%) and that of ascospores of Diporotheca (2-5\%) (Fig. 4) indicates major soil disturbance, extensive soil erosion, and phosphateeutrophication due to the impact of agricultural activites, and livestock trampling of marshland ecosystems (López-Sáez et al., 1998; van Geel et al., 1994, 1996; Hillbrand et al., 2012).

Some authors contend that these Chalcolithic communities of the lower Guadalquivir basin lived mostly on fish and shellfish, supposedly placing agricultural plots only on the eastern and northern edges of the Gualquivir paleoestuary (Escacena, 2001, 2014). However, regional paleodietary studies drawing on stable isotope analyses reveal a homogeneous diet based on C3 terrestrial plant and animal resources - meat, milk, and dairy products combined with pulses and cereals - with minor ingestion of aquatic foodstuff (Fontanalls- 
Coll et al., 2015). The data provided by the $\mathrm{S} 1$ pollen record are conclusive and in line with the paleodietary evidence: during the Chalcolithic, a mixed agricultural and livestock economy was practiced in the the DNP area, at least on both the eastern and western boundaries of the marshland, during a long chronological interval of almost a millennium ( 5000-4200 cal BP). Surely, these crops must have been grown in those areas with fertile soils (along the eastern edge) or in those places where fresh water was available, yet also in some enclaves of this type existing in the ecosystem mosaic of the DNP marshes, as evidenced by both freshwater-submerged and floating aquatic macrophytes in the S1 pollen record (Figs. 4-5). Perhaps such crops were grown as well on sandy extensions of the El Abalario field or on an early stage of the Doñana spit, today deeply buried (Fig. 6c).

The "dehesa" system - open savannah-like woodlands - represents a cultural landscape shaped by combined human and livestock pressure, i.e. an anthropozoogenous landscape resulting from farming and grazing activities in the oak forests (Quercus ilex and Q. suber). This system of agricultural exploitation of the forest originated in the western half of Iberia between the Late Neolithic and the Chalcolithic (Stevenson and Harrison, 1992; López-Sáez et al., 2005, 2007), linked to new concepts of landscape organization represented by the first megalithic tombs (García Sanjuán, 1999, 2005; Díaz-Zorita et al., 2012). The existence of a "dehesa" landscape in the DNP marshland during the Copper Age ( 5000-4200 cal BP) was the outcome of a rational, long-term management of the agroforestry resources, entailing a lasting sedenterisation of the population. In fact, areas with greater agricultural capacities, such as wetlands, were increasingly populated in southwestern Iberia from the Early Chalcolithic ( 5200 cal BP) (Balsera et al., 2015; Lillios et al., 2016), with very dense settlement of farmsteads, preferably in the valley floors and in the fertile countryside (García-Rivero, 2004), as cereal farming spread (Acosta, 1995; Mederos, 1996).

From $\sim 4500$ cal BP onwards, settlements diversified (Fig. 6b): some sites are small (1-5 ha) and are located on hills or in low-lying settings, comprising both open and walled sites (Cabezo de los Vientos, La Orden-Seminario, El Tejar, Rincón, and Papa Uvas in the Odiel-Tinto paleoestuary; Cerro de San Juan, Carmona, San Bartolomé de Almonte, Bonares, Mesas de Asta, and Lebrija in the vicinity of the Gualquivir paleoestuary; Monte Berrueco in the Guadalete estuary); other sites are large and unenclosed ( $>50$ ha) or represent so-called ditched mega-sites such as Valencina de la Concepción, across around 450 ha (Escacena and De Frutos, 1986; García Sanjuán and Hurtado, 1997; García-Sanz and Fernández-Jurado, 1999; Belén et al., 2000; Pérez-Macías et al., 2002; Abril, 2003; García-Rivero and Escacena, 2015; Garrido and Vera, 2015; García Sanjuán et al., 2017). At this time numerous Copper Age settlements stood at the mouth of the Guadalquivir river on the eastern edge of the DNP marshes (Arteaga and Roos, 1992, 1995; Fig. 6c). Abundant archaeological remains from the Late Neolithic and the Chalcolithic have also been found on the western active dune system of the DNP (Campos et al., 1993; Borja et al., 1999). The increase in both the total number of sites and the average size of the sites suggests that the Chalcolithic expansion was accompanied by a substantial growth of the population (Blanco-González et al., 2018). In fact, this period was the climax of a rising demographic trend favoured by a surplus economy practiced during the Late Neolithic (Acosta, 1995), driven in turn by technological advances such as the plough and animal traction 
(Sherrat, 1981; Harrison, 1995; García Sanjuán and Hurtado, 1997). In addition, zooarchaeological data from sites such as Papa Uvas and Valencina de la Concepción indicate the importance of bovines, pigs, and ovicaprines at that time (Harrison and Moreno, 1985; Martín de la Cruz, 1994), which agrees with the aforementioned strong pastoral pressure detected in the S1 pollen record.

Human and livestock impact on coastal woodland areas as well as expansion of agriculture have also been tracked $\sim 5000-4200 \mathrm{cal}$ BP in pollen records from nearby sites in Southwest Iberia (Figs. 6b-6c), such as El Acebrón, Las Madres, Asperillo, Marilópez, Marismillas, and S11 in the DNP and its vicinity (Caratini and Viguier, 1973; Stevenson, 1984, 1985; Stevenson and Moore, 1988; Stevenson and Harrison, 1992; Zazo et al., 1996; Yll et al., 2003; López-Sáez et al., 2011; Jiménez-Moreno et al., 2015), as well as at the archaeological site of Pocito Chico in the Cadiz Bay (López-Sáez et al., 2001, 2002). In the case of the El Acebrón peat bog pollen record (Stevenson and Moore, 1988), the above-mentioned human imprint during the $5^{\text {th }}$ millennium cal BP correlates with sedimentary bands rich in macrocharcoal, which would indicate the use of fire for deforestation by human communities. These data coincide with high concentrations of CHAR macrocharcoal particles $\sim 4890-4780$ cal BP $\left(143-331\right.$ particles $\left.\mathrm{cm}^{-2} \mathrm{yr}^{-1}\right)$ and $\sim 4700$ cal BP (269 particles $\mathrm{cm}^{-2} \mathrm{yr}^{-1}$ ) in the $\mathrm{S} 1$ record (Fig. 5).

The study area is only $40 \mathrm{~km}$ away from the Iberian Pyrite Belt (Fig. 6), one of the richest metallogenic zones of Western Europe (Mellado et al., 2006). Local metallurgy dates back to the first centuries of the $5^{\text {th }}$ millennium cal BP (Leblanc et al., 2000; Abril, 2003; Nocete et al., 2005, 2011); however, its scale and environmental impact are subject to ongoing debate (e.g., García-Alix et al., 2013). Some authors have argued for woodland-consuming copper production activities on a relatively large scale in the Aracena mountain range (Nocete et al., 2005, 2011); they claim that copper metallurgy conducted at Chalcolithic sites such as Cabezo Juré or Valencina de la Concepción would have caused a significant environmental impact. Deforestation of the landscape and pollution by heavy metals at both local and regional levels were the ultimate consequences of intensive metal mining activities (Nocete et al., 2005, 2008; Nocete, 2014). While diverse paleoecological records might support this view, their interpretation is not straightforward and other, simpler interpretations of the evidence are possible. These other scholars argue that copper metallurgy at this time was a localised domestic activity of part-time crafts people (Hunt, 2003; Costa et al., 2010; MurilloBarroso et al., 2015). Although pollen analyses from Cabezo Juré, La Junta de los Ríos, and Valencina de la Concepción (Fuentes et al., 2006; Nocete et al., 2004-2005, 2008) (Fig. 6b) show a certain increase in deforestation - the presence of poorly-developed oak woodlands - and erosive processes, metallurgy might not have been the only contributing activity. Holocene sediments from the Odiel-Tinto estuary contain high metal ( $\mathrm{Cu}, \mathrm{As}, \mathrm{Pb}, \mathrm{Au}, \mathrm{Hg}$ ) concentrations in layers dated to 4480 cal BP (Leblanc et al., 2000; Nocete et al., 2005). Moreover, in a study of the sedimentary infill of the Guadiana estuary Delgado et al. (2012) determined that anthropogenic sources of metals (indicated by enrichment of $\mathrm{Pb}, \mathrm{Co}, \mathrm{Ni}, \mathrm{Mn}$, and $\mathrm{Cu}$ ) prevailed over natural sources at that time ( $\sim 500$ cal BP). Nevertheless, more recent literature (García-Alix et al., 2013) challenges the interpretation of such anomalies in cultural terms. In the DNP, the geochemical analysis of the PN core (Carretero et al., 2010, 2011), very close to our S1 record (Fig. 6c), documented the 
first evidence of slight palaeocontamination $\sim 4500 \mathrm{cal} \mathrm{BP}$, probably related to the presence of settlements keen on working the ore deposits of the Iberian Pyrite Belt near the Agrio River in the vicinity of Aznalcóllar (Fig. 6b), a tributary of the Guadiamar River (Hunt, 2003; Gómez-Toscano, 2006; Tornos, 2008). The magnitude and traceability of such a pollution episode, however, must have been restricted to a local scale, since such observations have no supporting evidence in marine records in the Alboran Sea or in further terrestrial cores (Martínez-Puertas et al., 2010; García-Alix et al., 2013). On the other hand, the S1 record registers increase in CHAR microcharcoal particles from $\sim 4500$ cal BP onwards, with three maximum values (569, 413, and $399 \times 10$ particles $\mathrm{cm}^{-2}$ year $^{-1}$, respectively) 4480, 4360, and $4290 \mathrm{cal}$ BP (Fig. 5). These values may be due to fire-related activities in the Aracena range from $\sim 4500 \mathrm{cal} \mathrm{BP}$, including forest clearance and herding in addition to metallurgy. In short, pre-Bronze Age signatures of heavy metal pollution and deforestation remain open to a variety of conflicting explanations (García-Alix et al., 2013).

\subsection{Early Bronze Age ( 4200-3500 cal BP)}

The Copper Age-Early Bronze Age transition 4200-4000 cal BP was a threshold period in the landscape history of the DNP marshes. In the S1 record, the pollen zone LPAZ-4 records a sharp decline of low marsh (3-5\%) and Isoetes (2.3-3.7\%) percentages and the disappearance of both freshwater floating- and submerged-aquatic macrophyte pollen taxa (Figs. 4-5); this suggests the advent of a markedly arid climate phase, with salt concentration at the ground surface. This phase is characterized by the spread of halophytic herbaceous (high marsh) pollen taxa such as Chenopodiaceae (30-35\%), Artemisia (3.6-4.5\%), Apiaceae, Armeria/Limonium, and Frankenia, and the spread of submerged-aquatic macrophytes typical of saline or brackish waters such as Ruppia (5-9\%), Lemna (2.3\%), and Zannichellia (Fig. 4). On a regional scale, the decrease in deciduous Quercus percentages $(<2 \%)$ and the parallel increase in the evergreen Quercus values (4-5\%) are also documented (Fig. 3). Locally, in this period the "monte blanco" pollen taxa increase their values (14-15\%) - particularly Juniperus, Pistacia lentiscus, Cistus, and Halimium -, probably due to their xerophytic character (Figs. 3 and 5), while those of "monte negro" decrease significantly (Quercus suber 2.4-3.7\%, Pinus pinea 5-6.3\%). The joint occurrence (Fig. 4), in low percentages, of Spirogyra and Byssotecium circinans (3-5\%) may well be indicative of meso- to euthropic conditions in the marshland during a dry phase (van Geel et al., 1989; López-Sáez et al., 1998; van Geel and Aptroot, 2006).

During the transition from the $5^{\text {th }}$ to the $4^{\text {th }}$ millennia cal BP the study area was subjected to the effects of a short, abrupt climate change of extreme aridity, known as the " $4.2 \mathrm{kyr}$ cal BP event" (Magny, 1993, 2004) or "Bond Event 3" (Bond et al., 2001), which has been recognized as a marked aridification phase in the Mediterranean Iberian region (Jalut et al., 2009; Carrión et al., 2010). Evidence of the $4.2 \mathrm{kyr}$ cal BP event ( 4200-4000 cal BP) is present in the pollen record of the S11 core from the DNP (Jiménez-Moreno et al.,

2015), at El Acebrón and Las Madres in the Doñana territory (Stevenson and Moore, 1988; Stevenson and Harrrison, 1992; Yll et al., 2003), at Pocito Chico in the Cadiz Bay (López-Sáez et al., 2001, 2002), and in the Beliche marshland in the Guadiana estuary in southern Portugal (Fletcher et al., 2007) (Figs. 6b-6c); this 
evidence consists of increases in Chenopodiaceae and xerophytic taxa such as Juniperus and Artemisia, and conversely decreasing values of wetland taxa (Cyperaceae, Isoetes, Myriophyllum). A paleoclimatic reconstruction from the neighboring S11 pollen record indicates an abrupt decrease in the average annual rainfall of at least $45 \mathrm{~mm}$, which in turn, coincides with maxima in temperature parameters $\sim 4100$ cal BP (Lillios et al., 2016). A similar process happened in Medina Lake, as indicated by a marked lowering of the lake level and a loss of the diatom record $\sim 4100$ cal BP (Reed et al., 2001).

Nevertheless, $\sim 4200-3800$ cal BP (likely average date: $\sim 4000$ cal BP) a large extreme wave event (EWE) has also been documented, identified as a tsunami in other parts of Southwest Iberia. In the DNP marshland it is recorded as an interbedded marine layer made up of fine storm deposits and thicker tsunamiinduced shelly deposits; it is documented within the inner marsh deposits of the Guadalquivir paleoestuary (Rodríguez-Ramírez et al., 1996; Rodríguez-Ramírez and Yáñez, 2008; Lario et al., 2010, 2011). The occurrence of this EWE has also been inferred from the lithostratigraphy of the S1 core $\sim 4200-4000$ cal BP (EWE-2; Fig. 2) as well as from the neighboring borings of S7, S9, and S11 cores (Fig. 6c); it is characterised by sandy layers that contain massive accumulations of shells (both articulated and disarticulated bivalves) and shell fragments in a sandy-muddy matrix with gravel and lithoclasts, on an erosive base (Rodríguez-Ramírez et al., 2015). Very high values of Glomus (8-23\%) and Pseudoschizaea circula (9-16\%) can be also correlated with erosive processes derived from EWE-2 (Fig. 4), whereas percentage increases of HdV-222 (3-6\%) and HdV-229 (1.7-3.3\%) are related to the sandy deposits (van Geel et al., 1989).

The temporal coincidence of a climatic change with a high energy marine incursion of the possible tsunami in the DNP $\sim 4200-4000$ cal BP (Fig. 5) is likely to have had an effect on the Chalcolithic communities that occupied the territory. EWE-2 might have destroyed some of the settlements and reworked their remains across the estuarine basin (Rodríguez-Ramírez et al., 2015). This hypothesis is plausible if one takes into account that EWE-2 caused major geomorphological changes that are symptomatic of tsunamigenic processes of a large magnitude; these signs include (Fig. 6d) the breaching and sudden erosion of the Doñana spit barrier - including a large overwash of the southernmost section of the neighboring aeolian system of El Abalario - and the generation of large sandy cheniers (Carrizosa-Vetalarena, Los Acebuches) (Rodríguez-Ramírez et al., 2015; Celestino-Pérez et al., 2016). The rather catastrophic effects in the Guadalquivir estuary were compounded by the intense neotectonic subsidence detected in the area (Rodríguez-Ramírez et al., 2014).

The consequences of both climate change and the tsunamigenic event $\sim 4200-4000$ cal BP are clearly reflected in both the palynological and the archaeological records of the transitional period between the end of the Chalcolithic and the onset of the Early Bronze Age in the DNP. From a palynological point of view, in addition to what has already been commented on, there are almost no traces of anthropogenic impact on vegetation in the $\mathrm{S} 1$ sequence, neither in the charcoal nor in the pollen record (Figs. 3-5). Coprophilous fungi show a strong downward trend (0.4-2.6\%), especially Sordaria, Sporormiella, and Cercophora, while Chaetomium and Podospora disappear. In fact, the sporadic presence and low percentages of coprophilous 
fungi must be interpreted as a result of the movement of wild animals through the marshland and not domesticated livestock. Anthropogenic nitrophilous (3-5\%) and anthropozoogenous pollen taxa $(<1 \%)$ sharply decrease, suggesting a very low or no human impact and the end of arable (absence of cereal pollen) and pastoral activities. Furthermore, high values of Dinoflagellata (6-18\%) and Foraminiferae (2.24\%) suggest oceanic movements driven by high energy, which would have allowed these planktonic organisms to reach the interior of the paleoestuary. A similar picture can be gathered from other pollen records in Southwest Iberia (Figs. 6b-6c), such as S7, S11, El Acebrón, Las Madres, Pocito Chico, Medina, Beliche, Quarteira, Carcaxai, Alcantarilha, and Farelo-Torre (Stevenson and Moore, 1988; Stevenson and Harrrison, 1992; López-Sáez et al., 2001, 2002; Reed et al., 2001; Yll et al., 2003; Fletcher et al., 2007; JiménezMoreno et al., 2015; Schneider et al., 2016). From an archaeological point of view, the final result was the collapse of the Chalcolithic agrarian landscape in the DNP, a major decline in the number of settlements in coastal areas, and the emergence of a more pastoralist-oriented economy in mountain environments (e.g. the Aracena range) during the Early Bronze Age (Lillios et al., 2016; Blanco-González et al., 2018).

Subsequently, $\sim 4000-3500$ cal BP (LPAZ-5, 800-615 cm), the marshland ecosystem recovered to the vegetation conditions observed prior to EWE-2 (Figs. 3-5). While low marsh (48-70\%) and Isoetes (15-26\%) notably increased, high marsh taxa sharply decreased $(<10 \%)$. In addition, both freshwater-submerged (7$10 \%)$ and floating (6-10\%) aquatic macrophytes reappeared, as did other freshwater hydrophytic elements such as Phragmites (3.5-7\%), Typha angustifolia, and T. latifolia. Within NPPs, Pediastrum (2-4.3\%), Botrycoccus (2-3\%), Zygnema (1-2\%), Spirogyra (5-10\%), Gyratrix hermaphroditus (2-3\%), HdV-124, and HdV-18 reappeared (Fig. 4), suggesting humid and mesotrophic conditions (van Geel et al., 1989; van Geel and Aptroot, 2006). These data can be correlated with the humid phase described by Magny $(1993,2004)$ in the western Mediterranean $\sim 4000-3500 \mathrm{cal}$ BP. This stage would correspond to a period of relative stability of the marsh ecosystems, with higher rainfall and low sediment accumulation rates. Although the DNP paleoestuary may still have included a brackish lagoon, a certain saline influence is perceived in the record by the constant presence in it of Dinoflagellata in low percentages (Fig. 4). Pollen evidence of anthropization is still absent $\sim 4000-3500$ cal BP, which is consistent with very low percentages of both anthropogenic nitrophilous $(<4 \%)$ and anthropozoogenous herbs $(0-0.5)$ and coprophilous fungi $(<2 \%)$.

At the onset of the Early Bronze Age (EBA), 4200 cal BP, cultural changes occurred. Most Copper Age settlements were abandoned and new ones, such as El Trastejón and Papúa II (Fig. 6b), were established in the Aracena range $\sim 4200-3500$ cal BP (Hurtado et al., 2011), although such villages are poorly understood (García Sanjuán and Odriozola, 2012; Lillios et al., 2016). Moreover, there is a significant lack of EBA layers overlying the previous Chalcolithic occupations, suggesting the displacement of populations and their relocation elsewhere (García-Rivero and Escacena, 2015). Unlike the Chalcolithic settlement pattern, during the EBA the habitats are smaller and appear scattered throughout the study area (Fig. 6b), occupying very heterogeneous ecosystems between the coast (Monte Berrueco), the countryside (Tejada la Vieja, Papa Uvas, Valencina de la Concepción, Setefilla), and the mountains (Cabezo Juré) (Aubet et al., 1983; Escacena and De Frutos, 1985, 1986; Calderón et al., 1987; Caro-Bellido, 1988; Martín de la Cruz, 1994; Mederos, 1996; 
Nocete et al., 2005; García-Rivero and Escacena, 2015). Such a new settlement pattern is particularly evident on the eastern edge of the Doñana marshes (Figs. 6c-6d), where the number of EBA settlements is rather low when compared to those of the previous Chalcolithic period (Caro-Bellido, 1982, 1989; Arteaga and Roos, 1992, 1995).

These reasons, besides the ephemeral nature of habitats, have led some authors (García Sanjuán, 1999; Ruiz-Gil and López-Amador, 2001; Harding, 2003; López-Sáez et al., 2014) to posit that EBA communities had an economy with a spectrum of means of subsistence that was narrower than that of their Chalcolithic predecessors, who probably relied more on livestock than on arable agriculture and followed a more mobile lifestyle, with part of the population depending on herding strategies. Indeed, pollen records from El Trastejón and Papúa II (Fig. 6b) show a landscape during the EBA that was little affected by human impact and basically shaped by pastoral activities (high values of anthropozoogenous pollen taxa), with insignificant evidence of cereal pollen (Martín-Consuegra and Ubera, 2011). From 3700 cal BP onwards the availability of fertile zones near the EBA sites seems to be a location factor of minor importance, whereas their strategic position in hilly inexpugnable spurs gained importance (Campos and Gómez-Toscano, 1997; García Sanjuán, 1999). New prominent settlements were established in the EBA, some with massive terraces and stone-walls. The best-known site is El Trastejón, which features masonry slopes and terraces, with oval huts yielding evidence of copper smelting (Hurtado et al., 2011). In short, the Copper Age-EBA transition in the DNP is marked by an important decline of a human footprint. It is tempting to propose that the marsh environment suffered a substantial decline in population at the beginning of the Bronze Age $\sim 4200$ cal BP and those communities with different cultural backgrounds relocated to territories further inland. This suggested movement of local people is in line with the so-called 'replacement model' which envisages a cultural disruption at the Chalcolithic-EBA transition (García-Rivero and Escacena, 2015) and has led some authors to reconsider migration from the southwest to the southeast of the Iberian Peninsula after $\sim 4500 \mathrm{cal}$ $\mathrm{BP}$ as a plausible contributing factor to macro-regional dynamics (Lillios et al., 2016).

\subsection{Late Bronze Age ( 3500-2800 cal BP)}

Between $~ 3500$ and 3435 cal BP, a third EWE (EWE-3) is documented in the S1 record. This event has also been documented (Fig. 7b) in the neighboring records from S7 and S11 3550 cal BP (RodríguezRamírez et al., 2015). The sedimentological and faunal features of this third EWE make it difficult to establish whether it was a tsunami or a storm surge, however. Because of its central position in the paleoestuary, like S11, point S1 was more exposed to marine influence than S7, which was protected by the Doñana spit (Jiménez-Moreno et al., 2015). Northeast of S1, the Marilópez chenier system contains shells and shell fragments as a result of estuarine resedimentation associated with storms, tsunamis, currents, and other processes (Rodríguez-Ramírez et al., 1996; Ruiz et al., 2005b; Rodríguez-Ramírez and Yáñez, 2008). Other sandy littoral strands, such as those of Veta de Los Acebuches (Fig. 7b), also contain shells derived 
from different environments that have been dated to 3882-3334 cal BP (Rodríguez-Ramírez and Yáñez, 2008), thus indicating an estuary unrestricted by sandy barriers up to at least $\sim 3300$ cal BP.

From a palynological point of view, EWE-3 is correlated with pollen zone LPAZ-6, which registers (Figs. 3-5) a percentage increase of NPPs that indicate erosive events (Glomus, Pseudoschizaea circula). The sandrich deposits (HdV-222, HdV-229) are augmented in high marsh pollen taxa (13\%) and Ruppia (3.8\%), and there is a diminution of low marsh pollen taxa (29.3\%), Isoetes $(2.6 \%)$, and freshwater-submerged and floating aquatic macrophytes $(<1 \%)$. LPAZ-6 is also characterized by the reappearance of Foraminiferae (15.1\%) and an increase of Dinoflagellata (19.6\%), which suggests a paleoestuary relatively confined 3500-3435 cal BP but with remarkable marine influence. The percentage of anthropogenic nitrophilous herbs (1.4\%), anthropozoogenous herbs $(0 \%)$, and coprophilous fungi $(1.2 \%)$ is very low, indicating the absence of any type of human impact on the ecosystems of the marshland at this time.

In the post-EWE-3 phase, 3435-3185 cal BP (LPAZ-7), the high marsh becomes more important (21$24.6 \%$ ), while the low marsh (28-31.4\%) and Isoetes (7-8\%) seem to be reduced; qualitatively, however, the low marsh presents a high number of pollen taxa, like the freshwater-submerged (2\%) and floating aquatic macrophyte pollen taxa (3\%), which suggests the coexistence of very diverse communities in the marshland itself (Figs. 4-5). In fact, other aquatic macrophytes capable of withstanding a certain degree of salinity (Ruppia 6-9.4\%, Zannichellia 2-3.6\%, Lemna 2.4-4.3\%) also thrived at this time. Furthermore, "monte blanco" woodlands increase their values (10-11\%), to the detriment of "monte negro" ones, which, nonetheless, remain the dominant woodland types in the DNP (Fig. 5). As in the previous phase, the palynological evidence of anthropization is insignificant. The co-occurrence of Byssotecium circinans (511\%), HdV-181 (4-5\%), Pediastrum (9-13\%), Botryococcus (8-11\%), Zygnema (4-5\%), and Spirogyra (9$13 \%$ ) indicates meso- to euthropic conditions in the marshland during a marked arid phase in the brackish lagoon that occupied the paleoestuary (van Geel et al., 1989; López-Sáez et al., 1998; van Geel and Aptroot, 2006). The presence of sand in the sequence (Fig. 2) justifies the recurrence of HdV-222 and HdV-229 in the pollen record, while some marine influence is recorded by the presence, albeit in low percentages, of Dinoflagellata (4-7\%). All of these data can be correlated with the generalized climate aridification that affected the western Mediterranean during the mid-late Holocene, which seems to be due to the decreasing trend in summer insolation, lower sea-surface temperatures, and lower precipitation during the autumnwinter season (Magny, 1993, 2004; Jiménez-Moreno et al., 2015).

Later, a new EWE (EWE-4) is documented in the S1 record 3185-3140 cal BP, which has been also documented in the S7 and S11 records $~ 3150$ cal BP (Rodríguez-Ramírez et al., 2015). By taking into account the date of this event and its stratigraphic position, the EWE-4 deposit at point S1 can be attributed to a single event that spread across the paleoestuary and adapted to its paleogeography (Fig. 7c). The pollen spectra related to this fourth event (LPAZ-8) are very similar to those of LPAZ-6 (Figs. 3-5). However, unlike the previous EWEs, this one does seem to have had an important effect on the coastal woodlands of the DNP, since LPAZ-8 registers a decrease of both "monte blanco" (6.6-8\%) and "monte negro" pollen taxa $(<40 \%)$. Regression is more pronounced in salt-sensitive taxa (Quercus suber, evergreen Quercus) and 
seeders ("monte blanco" pollen taxa such as Pistacia lentiscus, Cistus or Halimium) (Figs. 3 and 5), due to seed bank burial or destruction (Miyamoto et al., 2004); by contrast, more salt-tolerant taxa (Pinus pinea, Olea europaea) and sprouters ("monte negro" pollen taxa such as Rhamnus lycioides or Phillyrea) seem to be less affected by the ingress of saline waters into the marshland. These facts corroborate the hypothesis that the marine flood could have varied impacts on the terrestrial vegetation of the DNP, where the individual response of each taxa would be related to ecological features such as salt tolerance, biotype, and interspecific competitiveness. In turn, the high marsh becomes more important (28-29\%), while the low marsh and freshwater aquatic macrophytes are significantly reduced. The erosive potential of EWE-4 is confirmed by maximum percentages of Glomus (14-16\%) and Pseudoschizaea circula (21-23\%), while the marine influence that it caused is documented by the reappearance of Foraminiferae (24.6-25.4\%) and a maximum of Dinoflagellata (32.4-35.3\%) (Fig. 4). Furthermore, LPAZ-8 registers no evidence of anthropization.

Such morphostratigraphic and palynological features lead us to consider EWE-4 as tsunamigenic, especially considering the distance of the three cores (S1, S7, S11) to the paleocoastaline (10-15 km), as well as the fact that similar events have been documented in the Tinto-Odiel and Guadalete paleoestuaries (Morales et al., 2008, 2011; Lario et al., 2010, 2011). EWE-4 must have brought about large and catastrophic geomorphological changes throughout the southwest of the Iberian Peninsula. In the Guadalquivir paleoestuary (Rodríguez-Ramírez et al., 2014, 2015) it caused extensive erosion of the Doñana spit and a rupture of the Algaida spit which transformed this spit into an island (Fig. 7c). Indeed, a high-energy layer has been found by means of shallow drilling of sediments in the eastern sector of the Gualdalquivir river bank, which appears to have been generated by this event (Rodríguez-Ramírez et al., 2015); in the marsh of Rajaldabas this layer contains remains - at almost $1 \mathrm{~m}$ depth - of an archaeological site dated, by artefact typology to the "Bronze II espagnol" ending abruptly 3200 cal BP (Menanteau, 1981) (Fig. 7c). Such abrupt change most likely occurred in other settlements in the DNP and certainly at nearby Lebrija, on the eastern paleocliffs of the paleoestuary (Tejera-Gaspar, 1985; Caro-Bellido et al., 1987). However, as previously noted, the pollen evidence of such other potential settlements in the DNP is practically nonexistent. The marsh of Rajaldabas is some $20 \mathrm{~km}$ away from the marsh of Hinojos and point S1.

Judging by the macrofaunal record in different cores (S1, S7, S11), the Guadalquivir paleoestuary became confined after EWE-4 (Rodríguez-Ramírez et al., 2015). Input of transported marine molluscs decreased and species from sheltered environments became dominant (Celestino-Pérez et al., 2016). Definitely, the transition from an open estuary to a semi-closed one can be dated in the S1 record to just after $\sim 3185-3140$ cal BP and could be related to coastal progradation and the formation of sandy barriers in the river mouth (Fig. 7d). These facts are clearly discernible in the S1 pollen record by the disappearance of Dinoflagetallae and Foraminiferae from $~ 3080 \mathrm{cal} \mathrm{BP}$ onwards (Fig. 4).

After EWE-4, the low-energy marine dynamics at work in the Gulf of Cadiz resumed their action: the Doñana spit started to grow again, even more towards the southeast than before, and fluvial inputs within the paleoestuary were reactivated, with the consequent stability of the marshland ecosystems. In fact, $\sim 3140$ - 
2800 cal BP (LPAZ-9) climatic conditions are those of a constant aridification process from $\sim 3000$ cal BP onwards, which means that high marsh developed (25-32\%), while low marsh (10-20\%), Isoetes, and aquatic freshwater macrophytes were significantly reduced (Figs. 4-5). In contrast, aquatic vegetation capable of withstanding a certain degree of salinity underwent a small increase or remained at values akin to the preceding pollen zone. The joint occurrence of Spirogyra (1-3\%), Zygnema (0.5-2.5\%), HdV-181 (1-4.3\%), Gyratrix hermaphroditus ( 1\%), Pediastrum (1-2\%), Botryococcus (1-2\%), and Byssotecium circinans (3$6 \%$ ) could indicate meso- to euthropic conditions in the marshland during a dry period (van Geel et al., 1989; López-Sáez et al., 1998; van Geel and Aptroot, 2006), while the presence of both HdV-222 and HdV229 until 2965 cal BP could relate to the existence of sands (Fig. 2) in the S1 lithostratigraphy (van Geel et al., 1989).

Unlike the previous pollen zone, in LPAZ-9 the evidence of anthropization is very compelling $\sim 3140$ 2800 cal BP (Fig. 5): anthropogenic nitrophilous (24-28\%) and anthropozoogenous herbs (5-6\%) sharply increase, as do coprophilous fungi (11-15.4\%); furthermore, cereal pollen reappears in the sequence, sometime - 3080 and 2965-2865 cal BP - with values above 3\%, which would imply admitting, again, the existence of agricultural crops in the immediate vicinity of the S1 core (López-Sáez and López-Merino, 2005). In parallel, both "monte blanco" $(<3 \%)$ and "monte negro" (Quercus suber $<2 \%$, Pinus pinea 5-7\%) seem to degrade, although certain pollen taxa characteristic of the degradative stages of these formations increase (Rivas-Martínez et al., 1980), such as Erica (2-5\%) and Pteridium aquilinum (3-5.3\%), as well as Poaceae (9-17\%) (Figs. 3-4). All of these developments chronologically coincide with an important settlement increase in the DNP environment during the pre-Phoenician Late Bronze Age (Fig. 7d). The reappearance of Anabaena (3-7\%), Aphanizomenon (1-4\%), and Diporotheca (2-5\%) 3140-2800 cal BP (Fig. 4) indicates extensive soil erosion and phosphate-eutrophication due to the impact of palaeoeconomic activites by LBA people (López-Sáez et al., 1998; van Geel et al., 1994, 1996; Hillbrand et al., 2012). These facts coincide with high concentrations of CHAR macrocharcoal particles $\sim 3040 \mathrm{cal}$ BP (289 particles cm$~^{-2}$ $\mathrm{yr}^{-1}$ ) and $\sim 2935-2900 \mathrm{cal}$ BP (167-313 particles $\left.\mathrm{cm}^{-2} \mathrm{yr}^{-1}\right)$ in the S1 record (Fig. 5), which would allow us to suggest the anthropogenic use of fire on a local and extra-local scale, both for growing crops and for clearing vegetation to create more pasture for cattle.

Our data from LPAZ-9 are supported by other pollen records from Southwest Iberia which show similar trends, such as those from El Acebrón, Las Madres, Marilópez, and S7 and S11 in the DNP and its vicinity (Stevenson, 1984, 1985; Stevenson and Moore, 1988; Stevenson and Harrison, 1992; Zazo et al., 1996; Yll et al., 2003; Jiménez-Moreno et al., 2015). They are also supported by the archaeological site of Pocito Chico in the Cadiz Bay, where the last centuries of the Bronze Age show a very evident human impact - high values of anthropogenic nitrophilous herbs and cereals, decrease of the arboreal cover - as a consequence of population increase (López-Sáez et al., 2001, 2002). In addition, the arid event 3000 cal BP has been locally recognized by the desiccation of Medina Lake (Reed et al., 2001); globally, the period 3140-3000 cal BP coincides with "Bond cold event 2" from the North Atlantic (Bond et al., 2001) and low lake levels in central Europe and the western Mediterranean (Magny, 1993, 2004). 
From a material culture viewpoint, it is necessary to distinguish the earliest centuries of the Late Bronze Age (LBA) ( 3500-3200 cal BP) from the latest, or Pre-Phoenician, LBA ( 3200-2800 cal BP). Only a few radiocarbon dates have been obtained in the region for this long period (García Sanjuán and Odriozola, 2012), to be supplemented by the dates on wooden parts of some metal items of a hoard found in the Huelva estuary $\sim 3080-2790$ cal BP (Ruiz-Gálvez, 1995b). In addition, the material culture does not offer diagnostic typological criteria with which to attribute assemblages to phases. Radiocarbon-dated LBA settlements in Southwest Iberia are few as well: El Trastejón, Setefilla, Monte Berrueco, and the mining camp of Chinflón (Pellicer and Hurtado, 1980; Rothemberg and Blanco, 1980; Aubet et al., 1983; Escacena and De Frutos, 1985; Mederos, 1996; Hurtado et al., 2011). This knowledge base is changing only slowly (e.g. contributions in Celestino-Pérez and Rodríguez, 2017).

During the LBA and the Early Iron Age (EIA), a major mining and metallurgical area can be identified in the Huelva region, in connection with copper and silver extraction in the Iberian Pyrite Belt and the presence of a natural harbour in the Huelva estuary (Hunt, 2003). Around 3200/3100 cal BP, tin-bronze items were ubiquitous in the study area; furthermore lead started circulating, both for producing ternary alloys $(\mathrm{Cu}, \mathrm{Sn}$, and $\mathrm{Pb}$ ) and for extracting noble metals from argentiferous galena. By then, local Bronze Age communities had practiced relatively simple, rudimentary metallurgical techniques to produce copper-based items and to benefit native silver ores, especially during the EBA (Hunt, 2003; Nocete et al. 2008, 2011; Nocete 2014). Although native silver is scarce in the region, argentiferous sulfurs proliferate and eastern Mediterranean know-how allowed the extraction of silver from them. Cupellation - a method for extracting silver from argentiferous jarosite adding lead - started being used around this time, likely via Phoenician craftmanship (Murillo-Barroso et al., 2016). At this juncture, the local abundance of argentiferous raw materials, the awareness of technology for extracting silver, and the circulation and availability of lead from elsewhere most likely from southeast Iberia - were crucial circumstances in boosting the scale and volume of local metallurgical activities. All in all, these developments made a difference with previous metallurgical activities in the earlier Bronze Age (Hunt, 2003; Ruiz-Mata and Gómez-Toscano, 2008; Murillo-Barroso et al., 2016) and had traceable effects in the landscape and social organization of LBA and EIA communities. In contrast to the hotly debated matter of pollution and deforestation during the Copper Age and the EBA in Southern Iberia, there is relative consensus on the likely impact of intensive mining and metallurgical activities in the LBA and especially during the EIA in the region (e.g. García-Alix et al., 2013). Extensive deforestation detected in the $\mathrm{S} 1$ record $\sim 3140$ to $2800 \mathrm{cal}$ BP might be attributed to social practices related to these intensive activities in the Huelva region (Stevenson and Harrison, 1992); S1 registers maximum values of CHAR microcharcoals $\sim 2965$ cal BP $\left(167\right.$ x 10 particles $\mathrm{cm}^{-2}$ year $\left.{ }^{-1}\right)$ and $\sim 2865-2830$ cal BP (119-223 x 10 particles $\mathrm{cm}^{-2}$ year $\left.^{-1}\right)$, as well as a remarkable decrease in deciduous Quercus values $(<1 \%)$ (Figs. 3 and 5).

It is probable that the gaining importance of mining and metallurgy had a severe environmental effect across the Aracena (range) landscape during the LBA; this is suggested by the pollen record from El Trastejón (García Sanjuán, 1999; Hurtado et al., 2001), which shows a highly deforested and anthropized 
landscape - high values of nitrophilous pollen taxa -, with a mixed economy of arable agriculture (presence of pollen of cereals and Vicia faba) and livestock farming (high percentages of anthropozoogenous pollen taxa) (Martín-Consuegra and Ubera, 2011). This trend is also visible in the woodlands of the DNP, judging by the $\mathrm{S} 1$ pollen record (Fig. 5).

The lifestyles, settlement forms, and even the effective occupation and permanence of local communities during the LBA in the study area are the subject of conflicting points of view. LBA habitats and domestic quarters in Southwest Iberia prior to the Phoenician arrival $\sim 2800 \mathrm{cal}$ BP are scarce and poorly documented. The absence of diagnostic features in the material culture hinders typological dating (Belén et al., 1992; Belén and Escacena, 1995; Ruiz-Gil and López-Amador, 2001; Torres-Ortiz, 2002; Suárez and Márquez, 2014; Ferrer, 2017). Around 3400 cal BP, small coastal outposts were founded on promontories and natural shelters such as at Tarifa, Huelva, and El Carambolo (Fig. 7a). They are regarded as nautical stopovers related to long-distance exchange with the earliest central and eastern Mediterranean seafarers (Delgado, 2013). Further inland, LBA villages were often founded on hills and constructed with stone-walls (Fig. 7a), such as at Los Castrejones and El Castillo on the Agrio River (Aznalcóllar) or Niebla on the Tinto River (Hunt, 2003; Campos et al., 2006; Gómez-Toscano, 2006, 2009; Ruiz-Mata and Gómez-Toscano, 2008). Further inland, sites such as Pocito Chico, Acinipo, and Montemolín (Suárez and Márquez, 2014) comprise a few huts with oval plants, stone foundations, and earthen walls lacking inner divisions, looking like previous EBA huts such as those at El Trastejón (Hurtado et al., 2011; Suárez and Márquez, 2014).

Some authors have argued for a settlement hiatus in Southwest Iberia during the final LBA $(\sim 3200-2800$ cal BP), just before the arrival of the Phoenicians $\sim 2800$ cal BP (e.g. Belén et al., 1992; Belén and Escacena, 1995; García Sanjuán and Odriozola, 2012; Escacena, 2014). Thus, for these authors a weak LBA demography would have been followed by a sharp population growth in the EIA. Others, by contrast, have argued against any such population decline during the local LBA, claiming that this is a misleading image and reflects insufficient fieldwork (e.g. Gómez-Toscano, 2006, 2008; Gómez-Toscano and Campos, 2008; Gómez-Toscano and Fundoni, 2010-2011; Gómez-Toscano et al., 2014). Gómez-Toscano and Campos (2008) have posited an early demographic increase and economic intensification in the region already in the LBA 3200-2800 cal BP, before the arrival of the Phoenicians. For them, a sufficiently complex political and economic organization was necessary to attract foreign trade (Ruiz-Gálvez, 2013). This involved the organization of the territory to obtain specific resources, such as minerals and metal bearing ores in Aznalcóllar, an expanding agriculture regime that included vine-growing areas, and relatively complex farming systems (Vera and Echevarría, 2013). It also entailed the control of communications, both terrestrial routes and the outpost of Huelva, where Atlantic and Mediterranean products, ideas, and techniques circulated and were exchanged during the latest Bronze Age, before the Phoenician diaspora in the early $3^{\text {rd }}$ millennium cal BP (Ruiz-Gálvez, 1995a, 2013; Gómez-Toscano and Fundoni, 2010-2011; Gómez-Toscano et al., 2014).

The paleoenvironmental record from the S1 core is highly significant in this regard (Figs. 3-5). In our view, the S1 pollen record demonstrates, without ambiguity, that human impact in the particular local setting 
of the DNP fluctuated and was very uneven from a diachronic approach. For the first phase of the LBA ( 3500-3140 cal BP; LPAZ-6 to LPAZ-8), no palynological evidence of anthropization is detected: cereal pollen is absent, anthropogenic nitrophilous and anthropozogenous pollen taxa values are very low and coprophilous fungi values are negligible. Thus, only sporadic evidence of human and livestock presence can be inferred from such weak signatures. For the second phase of the LBA ( 3140-2800 cal BP; LPAZ-9), on the contrary, evidence of the human footprint in the DNP is unquestionable, as witnessed by the percentage increase in anthropogenic nitrophilous herbs, anthropozoogenous taxa, and coprophilous fungi, yet also by a substantial increase in CHAR values and the reappearance of cereal pollen. Therefore, judging by the S1 pollen record, there was more intensive use of the local environment and a clear return of human populations to the Doñana marshes from 3140 cal BP onwards, the last centuries of the LBA.

It can be hypothesised that the two EWEs registered in the Doñana marshland during the LBA, 35003435 cal BP (EWE-3) and 3185-3140 cal BP (EWE-4), reduced settlement to a very limited number of locations, barely traceable in the palaeoenvironmental record (e.g. the "Bronze espagnol II" at the marsh of Rajaldabas site). This hypothesis is even probable if we take into account that in the period between both EWEs - 3435-3185 cal BP - the S1 pollen record does not show any evidence of human activity. After EWE-4, during the pre-Phoenician Late Bronze Age, by contrast, the marshland ecosystems of Doñana began to suffer again from the impact of anthropogenic activities (agriculture, livestock, fires, deforestation); people migh have resettled this marshland setting again, after some centuries of isolation.

\section{Conclusions}

A multi-proxy approach has proved a powerful tool to identify environmental changes $\sim 5000-2800 \mathrm{cal}$ BP in the present-day marshes of the Doñana National Park. Major changes in vegetation composition and structure of the marshland ecosystems couple with paleoestuary configuration, climate variability, and human dynamics. The low marsh and both freshwater-submerged and floating aquatic macrophyte communities dominated during the humid periods, when the Guadalquivir paleoestuary harboured a brackish lagoon. In contrast, in the arid periods (e.g. beginning from $4.2 \mathrm{kyr}$ cal BP) the high marsh was the dominant vegetation and more salt - as a consequence of an EWE - concentrated in the ground. The amplitude of the vegetation response shows the elasticity and resilience of marshland communities to changes in the morphosedimentary environment. In any case, the aquatic habitats of the Doñana marshland are enormously heterogeneous and fluctuating, depending on the marine influence, the tides, and the Holocene evolution of the paleoestuary. For all these reasons, it must be understood that the marshland ecosystem is a mosaic of plant communities in which species with very different ecologies can coexist.

Our study is the first to be carried out at high-resolution in the Donana National Park, relating vegetation history, cultural dynamics, and human impact with climatic variability and the potential effects of extreme wave events on settlement patterns during the Copper and Bronze Ages. In this sense, the paleoenvironmental record at the S1 point, in the middle of the present-day low marsh of Hinojos, has 
proved to be sufficiently sensitive to detect the strategies and palaeoeconomic activities of the prehistoric populations living in the paleoestuary. During the Chalcolithic, $~ 5000-4200$ cal BP, in addition to potential fishing and shellfishing activities - not yet well researched -, settlements in the DNP area relied on important arable and pastoral activities, which are recorded in the S1 pollen record by an increase in both anthropogenic nitrophilous and anthropozoogenous herbs and coprophilous fungi. This evidence is clearly at variance with the prevailing understanding documented in the archaeological literature regarding the genesis of the present-day marshland in the paleoestuary; according to these archaeological sources, the paleoestuary was nothing but a slowly-evolving large gulf from the Postglacial Maximum to the Roman period. By contrast, during the Early Bronze Age ( 4200-3500 cal BP) and the first phase of the Late Bronze Age $(\sim$ 3500-3140 cal BP), arable activity and livestock husbandry activities ceased, as evidence of anthropization is practically non-existent in the S1 pollen record for these periods. It is likely that the impact of three EWEs over such a time span ( 4200-4000, 3500-3435 and 3185-3140 cal BP) limited not only the number of settlements in the DNP area and its vicinity but also their possible economic activities. These observations allow us to hypothesize the effective depopulation - or the ephemeral occupation by small scattered groups of the study area during both phases. Later, during the pre-Phoenician Late Bronze Age ( 3140-2800 cal BP), the study area was resettled and the impact of human subsistence practices (agriculture, livestock raising, fires, deforestation) left recognisable traces on vegetation formations in a context of increasing climatic aridification. Overall, this account serves to enhance the cyclical, punctuated nature of local settlement dynamics during the studied timeframe.

Geomorphological, palaeobiological, and sedimentological features generated by EWEs during the Holocene are common along the coasts of the Gulf of Cadiz, having been assigned to either tsunamis or storm surges. However, except for a few examples, palaeoenvironmental data are not always conclusive enough to determine without ambiguity whether tsunamis or storms-surges were the real cause of such features. It would be advisable to extend the detailed study of the record of EWEs to determine their true origin, as well as to accurately establish their cause-effect relationship on prehistoric and historic settlement models and on the evolution followed by marshland ecosystems. Similarly, in order to adequately assess both vegetation dynamics and prehistoric occupation of these territories, more high-resolution palaeoenvironmental studies are needed, since the vast majority of those carried out so far have failed to meet this methodological approach.

Finally, attention should also be given to both the calibration of radiocarbon dates obtained in these marshland contexts in Southwest Iberia and the correction of the reservoir effect on samples from marine shells. Correction of this effect not only depends on the geographical location of the samples to date but also of its uncalibrated age. It is important to point out that in many cases bulk sediment has been dated without correcting for the reservoir effect. Such an oversight can result in a significant methodological error, since the sediments of the Doñana marshland usually contain millimeter fragments of marine shells and degraded remains of aquatic plants that are also a source of the hardwater effect, the magnitude of which has not been measured yet. 


\section{Acknowledgements}

This work was funded by the project Relictflora-P11-RNM-7033 (Excellence Research Projects Program from the Andalusian Government). We are indebted to Fundación Caja de Madrid, Fundación Doñana 21, Ayuntamiento de Hinojos, Fundación FUHEM, Estación Biológica de Doñana (EBD), Espacio Natural de Doñana (END), Instituto Andaluz del Patrimonio Histórico (IAPH), Delegación de Cultura of Junta de Andalucía in Huelva, and Organismo Autónomo Parques Nacionales of Ministerio de Medio Ambiente y Medio Rural y Marino. Without their encouragement and support, the Hinojos Project would never have started. The present paper is a contribution to IGCP 588, "Preparing for coastal change," and to the INQUA Coastal and Marine Processes Commission. RLL is funded by a FPU grant (Spanish Ministry of Education, Culture and Sports); JNPA is member of the research groups RNM-190 (Junta de Andalucía) and GRC Geociències Marines (2017 SGR 315, Generalitat de Catalunya). Additional support by Junta de Andalucía to the Research Group RNM276 is also acknowledged. Thanks to an anonymous reviewer for their constructive comments on the manuscript.

\section{References}

Abril, M.V., 2003. Comunidades calcolíticas del Suroeste de la Península Ibérica: Santa Justa y Los Vientos. Huelva Arqueol. 18, 55-105.

Acosta, P., 1995. Las culturas del Neolítico y el Calcolítico en Andalucía Occidental. Espacio, Tiempo y Forma, Serie I, Prehistoria y Arqueología 8, 33-80.

Arteaga, O., Roos, A.M., 1992. El Proyecto Geoarqueológico de las Marismas del Guadalquivir. Perspectivas arqueológicas de la campaña de 1992. Anuario Arqueológico de Andalucía 2, 329-339.

Arteaga, O., Roos, A.M., 1995. El problema del "Lacus Ligustinus". Investigaciones geoarqueológicas en torno a las Marismas del Bajo Guadalquivir. In: Congreso Conmemorativo del V Symposium Internacional de Prehistoria Peninsular. Ayuntamiento de Jerez, Jerez de la Frontera, pp. 99-135.

Arteaga, O., Barragán, D., Roos, A.M., Schulz, H.D., 2016. Primicia cartográfica del río Guadalquivir hace 6500 años. Revista Atlántica-Mediterránea 18, 139-161.

Asensi, A., Díez-Garretas, B., 1987. Andalucía occidental. In: Peinado M., Rivas-Martínez, S. (Eds.), La vegetación de España. Universidad de Alcalá, Alcalá de Henares, pp. 197-230.

Aubet, M.E., Serna, M.R., Escacena, J.L., Ruiz, M.M., 1983. La Mesa de Setefilla (Lora del Río, Sevilla). Campaña de 1979. Excavaciones Arqueológicas en España 122, Ministerio de Cultura, Madrid.

Balsera, V., Bernabeu, J., Costa-Caramé, M., Díaz-del-Río, P., García Sanjuán, L., Pardo, S., 2015. The radiocarbon chronology of Southern Spain'late Prehistory (5600-1000 cal BC): A comparative review. Oxford J. Archaeol. 34, 139-156.

Behre, K.E., 1981. The interpretation of anthropogenic indicators in pollen diagrams. Pollen \& Spores 23, $225-245$. 
Bejarano, R., 1997. Vegetación y paisaje en la costa atlántica de Andalucía. Universidad de Sevilla, Sevilla. Belén, M., Escacena, J.L., 1995. Acerca del horizonte de la Ría de Huelva. Consideraciones sobre el final de la Edad del Bronce en el Suroeste ibérico. Complutum extra 5, 85-114.

Belén, M., Escacena, J.L., Bozzino, M.I., 1992. Las comunidades prerromanas de Andalucía Occidental. Complutum 2/3, 65-87.

Belén, M., Anglada, R., Conlin, E., Gómez, T., Jiménez, A., 2000. Expresiones funerarias de la Prehistoria reciente de Carmona (Sevilla). Spal 9, 385-403.

Benito-Garzón, M., Sánchez de Dios, R., Sainz-Ollero, H., 2007. Predicitve modelling of tree species distributions on the Iberian Peninsula during the Last Glacial Maximum and Mid-Holocene. Ecography $30,120-134$.

Bennett, K.D., 1996. Determination of the number of zones in a biostratigraphical sequence. New. Phytol. $132,155-170$.

Beug, H.J., 2004. Leitfaden der Pollenbestimmung für Mittleleuropa und angrenzende Gebeite. Gustav Fisher Verlag, Stuttgart.

Blaauw, M., 2010. Methods and code for classical age-modelling of radiocarbon sequences. Quat. Geochronol. 5, 512-518.

Blanco-González, A., Lillios, K.T., López-Sáez, J.A., Drake, B.L., 2018. Cultural, demographic and environmental dynamics of the Copper and Early Bronze Age in Iberia (3300-1500 BC): towards an interregional multiproxy comparison at the time of the $4.2 \mathrm{ky}$ BP event. J. World Prehist. 31, 1-79.

Bond, G., Kromer, B., Beer, J., Muscheler, R., Evans, M.N., Showers, W., Hoffmann, S., Lotti-Bond, R., Hajdas, I., Bonani, G., 2001. Persistent solar influence of North Atlantic climate during the Holocene. Science 294, 2130-2136.

Borja, F., Zazo, C., Dabrio, C.J., Díaz del Olmo, F., Goy, J.L., Lario, J., 1999. Holocene aeolian phases and human settlements along the Atlantic coast of southern Spain. Holocene 9, 333-339.

Cabezudo, B., 1979. Plantas de la Reserva Biológica de Doñana (Huelva). II. Lagascalia 8, 167-181.

Calderón, T., Sibelia, E., Fernández, J., 1987. Datación absoluta por termoluminiscencia y analítica de cerámicas arqueológicas en la Universidad Autónoma de Madrid. Cuad. Prehist. Arqueol. UAM 15, 385397.

Campos, J.M., Gómez-Toscano, F., 1997. La ocupación humana entre los tramos bajos del Guadiana y el Guadalquivir. Su incidencia en la evolución de la costa holocena. In: Rodríguez-Vidal, J. (Ed.), Cuaternario Ibérico, AEQUA, Huelva, pp. 305-313.

Campos, J.M., Borja, F., Gómez-Toscano, F., García-Rincón, J.M., Castiñeira, J., 1993. Medio natural y condiciones de hábitat en las formaciones arenosas de Doñana: Prospección arqueológica superficial. Anuario Arqueológico de Andalucía 2, 235-238.

Campos, J.M., Gómez-Toscano, F., Pérez, J.A., 2006. Ilipla-Niebla. Evolución urbana y ocupación del territorio. Universidad de Huelva, Huelva. 
Cantos, M., Arroyo, R., García, J.L., Lara, M., Morales, R., López, M.A., Gallardo, A., Alvar, C., Rodríguez, A., Valle, J.M., Vaca, R., González, M., Bánáti, H., Ocete, R., 2017. Current distribution and characterization of the wild grapevine populations in Andalusia (Spain). C. R. Biologies 340, 164-177.

Caratini, C., Viguier, C., 1973. Étude palynologique et sédimentologique des sables holocènes de la falaise littorale d'El Asperillo (Province de Huelva). Est. Geol. 29, 325-328.

Carcaillet, C., Bouvier, M., Fréchette, B., Larouche, A.C., Richard, P.J.H., 2001. Comparison of pollen-slice and sieving methods in lacustrine charcoal analyses for local and regional fire history. Holocene 11, 467476.

Caro-Bellido, A., 1982. Notas sobre el Calcolítico y el Bronce en el borde de las marismas de la margen izquierda del Guadalquivir. Gades 9, 71-90.

Caro-Bellido, A., 1988. Los comienzos del II milenio a.C. en el Bajo Guadalquivir: el tránsito del Cobre al Bronce. Zephyrus 41, 229-239.

Caro-Bellido, A., 1989. Consideraciones sobre el Bronce antiguo y pleno en el Bajo Guadalquivir. In: Aubet, M.E. (Ed.), Tartessos. Arqueología Protohistórica del Bajo Guadalquivir. Ausa, Barcelona, pp. 85-120.

Caro-Bellido, A., Acosta Martínez, P., Escacena, J. L., 1987. Informe sobre la prospección arqueológica con sondeo estratigráfico en el solar de la calle Alcazaba (Lebrija, Sevilla). Anuario Arqueológico de Andalucía 1986/II, 164-178.

Carretero, M.I., Pozo, M., Gómez, F., Ruiz, F., Abad, M., González-Regalado, M.L., Rodríguez-Vidal, J., Cáceres, L.M., Toscano, A., Baptista, M.A., Silva, P., Font, E., 2010. Primeras evidencias de contaminación histórica en el Parque Nacional de Doñana (SO de España). Stud. Geol. Salmanticen. 46, $65-74$.

Carretero, M.I., Pozo, M., Ruiz, F., Rodríguez-Vidal, J., Cáceres, L.M., Abad, M., Muñoz, J.M., Gómez, F., Campos, J.M., González-Regalado, M.L., Olías, M., 2011. Trace elements in Holocene sediments of the southern Doñana National Park (SW Spain): historical pollution and applications. Environ. Earth Sci. 64, $1215-1223$.

Carrión, J.S., Navarro, C., Navarro, J., Munuera, M., 2000a. The distribution of cluster pine (Pinus pinaster) in Spain as derived from palaeoecological data, relationships with phytosociological classification. Holocene 10, 243-252.

Carrión, J.S., Parra, I., Navarro, C., Munuera, M., 2000b. Past distribution and ecology of the cork oak (Quercus suber) in the Iberian Peninsula: a pollen-analytical approach. Divers. Distrib. 6, 29-44.

Carrión, J.S., Finlayson, C., Fernández, S., Finlayson, G., Allué, E., López-Sáez, J.A., López-García, P., GilRomera, G., Bailey, G., González-Sampériz, P., 2008. A coastal reservoir of biodiversity for Upper Pleistocene human populations: palaeoecological investigations in Gorham's Cave (Gibraltar) in the context of the Iberian Peninsula. Quat. Sci. Rev. 27, 2118-2135.

Carrión, J.S., Fernández, S., González-Sampériz, P., Gil-Romera, G., Badal, E., Carrión-Marco, Y., LópezMerino, L., López-Sáez, J.A., Fierro, E., Burjachs, F., 2010. Expected trends and surprises in the 
Lateglacial and Holocene vegetation history of the Iberian Peninsula and Balearic Islands. Rev. Palaeobot. Pal. 162, 458-475.

Celestino-Pérez, S., Rodríguez, E. (Eds.), 2017. Territorios comparados: los valles del Guadalquivir, el Guadiana y el Tajo en época tartésica. CSIC, Mérida.

Celestino-Pérez, S., Rafel, N., Armada, X.L. (Eds.), 2008. Contacto cultural entre el Mediterráneo y el Atlántico (siglos XII-VIII ane). La precolonización a debate. CSIC, Madrid.

Celestino-Pérez, S., Cerrillo-Cuenca, E., León, Á., López-Sáez, J.A., Pérez-Asensio, J.N., RodríguezRamírez, A., Villarías-Robles, J.J.R., 2016. Razones geológicas, arqueológicas y antropológicas de la conservación de Doñana: el Proyecto Hinojos (2005-2013). Arbor Anejos 11, 81-100.

Clemente, L., Siljeström, P., Rodríguez-Ramírez, A., 1997. Relación suelo/geomorfología en el Parque Nacional de Doñana. Cuat. Geomor. 11, 33-41.

Cortés-Sánchez, M., Morales, A., Simón, M.D., Bergadà, M.M., Delgado, López-García, P., López-Sáez, J.A., Lozano, M.C., Riquelme, J.A., Roselló, E., Sánchez-Marco, A., Vera-Peláez, J.L., 2008. Paleoenvironmental and cultural dynamics of the coast of Málaga (Andalusia, Spain) during the Upper Pleistocene and early Holocene. Quat. Sci. Rev. 27, 2176-2193.

Cortés-Sánchez, M., Morales, A., Simón, M.D., Lozano, M.C., Vera, J.L., Finlayson, C., Rodríguez-Vidal, J., Delgado, A., Jiménez, F.J., Martínez, F., Martínez, M.A., Pascual, A.J., Bergadà, M.M., Gibaja, J.F., Riquelme, J.A., López-Sáez, J.A., Rodrigo, M., Sakai, S., Sugisaki, S., Finlayson, G., Fa, D., Bicho, N.F., 2011. Earliest known use of marine resources by Neanderthals. PLoS One 6, e24026.

Cortés-Sánchez, M., Jiménez, F., Simón, M.D., Gibaja, J.F., Faustino, A., Martínez, F., Rodrigo, M., Flores, J.A., Paytan, A., López-Sáez, J.A., Peña, L., Carrión, J.S., Morales, A., Roselló, E., Riquelme, J.A., Dean, R.M., Salgueiro, E., Martínez, R.M., De la Rubia, J.J., Lozano, M.C., Vera, J.L., Llorente, L., Bicho, N.F., 2012. The Mesolithic-Neolithic transition in southern Iberia. Quat. Res. 77, 221-234.

Costa, M.E., Díaz-Zorita, M., García Sanjuán, L., Wheatley, D., 2010. The Copper Age settlement of Valencina de la Concepción (Seville, Spain): Demography, metallurgy and spatial organization. Trab. Prehist. 67, 85-117.

Costa-Tenorio, M., Morla, C., Sainz-Ollero, H., 1997. Los bosques ibéricos. Una interpretación geobotánica. Editorial Planeta, Barcelona.

Cugny, C., Mazier, F., Galop, D., 2010. Modern and fossil non-pollen palynomorphs from the Basque mountains (western Pyrenees, France): the use of coprophilous fungi to reconstruct pastoral activity. Veget. Hist. Archaeobot. 19, 391-408.

Delgado, A., 2013. Households, merchants, and feasting. Socioeconomic dynamics and commoners' agency in the emergence of the Tartessian world (eleventh to eighth centuries B.C.). In: Cruz Berrocal, M., García Sanjuán, L., Gilman, A. (Eds.), The Prehistory of Iberia, Debating Early Social Stratificaction and the State. Routledge, London, pp. 311-336. 
Delgado, J., Boski, T., Nieto, J.M., Pereira, L., Moura, D., Gomes, A., Sousa, C., García-Tenorio, R., 2012. Sea-level rise and anthropogenic activities recorded in the late Pleistocene/Holocene sedimentary infill of the Guadiana Estuary (SW Iberia). Quat. Sci. Rev. 33, 121-141

Díaz-Paniagua, C., Fernández-Zamudio, R., Florencio, M., García-Murillo, P., Gómez-Rodríguez, C., Portheault, A., Serrano, L., Siljeström, P., 2010. Temporary ponds from Doñana National Park: a system of natural habitats for the preservation of aquatic flora and fauna. Limnetica 29, 41-58.

Díaz-Zorita, M., Costa, M.E., García Sanjuán, L., 2012. Funerary practices and demography from the Mesolithic to the Copper Age in Southern Spain. In: Gibaja, J.F., Carvalho, A., Chambon, P. (Eds.), Funerary practices in the Iberian Peninsula from the Mesolithic to the Chalcolithic. BAR International Series 2417, Oxbow Books, Barnsley, pp. 51-62.

Escacena, J.L., 2001. Fenicios a las puertas de Tartessos. Complutum 12, 73-96.

Escacena, J.L., 2014. El desembarco de Noé. Sobre la primera neolitización de la paleoensenada bética. In: Parodi, M.J. (Coord.), Ex Illo Tempore, Actas de las I Jornadas de Arqueología del Bajo Guadalquivir. Fundación Casa Medina Sidonia, Sanlúcar de Barrameda, pp. 59-129.

Escacena, J.L., De Frutos, G., 1985. Estratigrafía de la Edad del Bronce en el Monte Berrueco (Medina Sidonia, Cádiz). Noticiario Arqueológico Hispánico 24, 7-90.

Escacena, J.L., De Frutos, G., 1986. El tránsito del Calcolítico al Bronce a través del 'Monte Berrueco' de Medina Sidonia (Cádiz). Trab. Prehist. 43, 61-84.

Espinar, J.L., 2004. Ecología de las comunidades de grandes helófitos de la marisma del Parque Nacional de Doñana. PhD dissertation, Universidad de Sevilla, Sevilla.

Fernández, N., Paruelo, J.M., Delibes, M., 2010. Ecosystem functioning of protected and altered Mediterranean environments: A remote sensing classification in Doñana, Spain. Remote Sens. Environ. $114,211-220$.

Fernández-Delgado, C., 2006. Conservation management of a European natural area: Doñana National Park, Spain. In: Groom, M.J., Meffe, G.K., Carroll, C.R. (Eds.), Principles of conservation biology. Sinauer Associates, Sunderland, pp. 536-543.

Fernández-Flores, A., García Sanjuán, L., Díaz-Zorita, M. (Eds.), 2016. Montelirio. Un gran monumento megalítico de la Edad del Cobre. Junta de Andalucía, Sevilla.

Ferrer, E., 2017. La colonización fenicia en la Tartéside: estrategias y fases. In: Celestino-Pérez, S., Rodríguez, E. (Eds.), Territorios comparados: los valles del Guadalquivir, el Guadiana y el Tajo en época tartésica. CSIC, Mérida, pp. 11-46.

Finlayson, G., Finlayson, C., Recio-Espejo, J.M., 2008. Dynamics of a thermo-Mediterranean coastal environment - the Coto Doñana National Park. Quat. Sci. Rev. 27, 2145-2152.

Fletcher, W., Boski, T., Moura, D., 2007. Palynological evidence for environmental and climate change in the Lower Guadiana valley (Portugal) during the last 13,000 years. Holocene 17, 479-492. 
Fontanalls-Coll, M., Díaz-Zorita, M., Subirà, M.E., 2015. A Palaeodietary Study of Stable Isotope Analysis from a High-status Burial in the Copper Age: The Montelirio Megalithic Structure at Valencina de la Concepción-Castilleja de Guzmán, Spain. Int. J. Osteoarchaeol. 26, 447-459.

Fuentes, N., Carrión, J. S., Fernández, S., González-Sampériz, P. Nocete, F., Lizcano, R., 2006. Análisis polínico del yacimiento arqueológico de La Junta (Puebla de Guzmán, Huelva). Anal. Biol. 28, 73-83.

Galiano, E.F., Cabezudo, B., 1976. Plantas de la Reserva Biológica de Doñana (Huelva). Lagascalia 6, 117176.

García-Alix, A., Jiménez-Espejo, F.J., Lozano, J.A., Jiménez-Moreno, G., Martínez-Ruiz, F., García Sanjuán, L., Aranda, G.; García-Alfonso, E., Ruiz-Puertas, G., Anderson, R.S., 2013. Anthropogenic impact and lead pollution throughout the Holocene in Southern Iberia. Sci. Total Environ. 449, 451-460.

García-Murillo, P., Fernández-Zamudio, R., Cirujano, S., Sousa, A., Nieto, I., Andújar, J., León, D., 2007. Flora y vegetación de la marisma de Doñana en el marco del proyecto de restauración ecológica Doñana 2005. Limnetica 26, 319-330.

García-Novo, F., Marín-Cabrera, C. (Eds.), 2006. Doñana. Water and biosphere. Doñana 2005 project, Guadalquivir Hydrologic Basin Authority and Spanish Ministry of Environment, Madrid.

García-Rivero, D., 2004. Prehistoria y evolución: reflexiones sobre la secuencia ecológico-cultural holocénica en el mediodía ibérico. Spal 13, 9-34.

García-Rivero, D., Escacena, J.L., 2015. Del Calcolítico al Bronce antiguo en el Guadalquivir inferior. El Cerro de San Juan (Coria del Río, Sevilla) y el 'modelo de reemplazo'. Zephyrus 76, 15-38.

García Sanjuán, L., 1999. Expressions of inequality: settlement patterns, economy and social organization in the southwest Iberian Bronze Age (c. 1700-1100 BC). Antiquity 73, 337-351.

García Sanjuán, L., 2005. Las piedras de la memoria. La permanencia del megalitismo en el Suroeste de la Península Ibérica durante el II y el I milenos a.n.e. Trab. Prehist. 62, 85-109.

García Sanjuán, L., Hurtado, V., 1997. Los inicios de la jerarquización social en el Suroeste de la Península Ibérica (c. 2500-1700 a.n.e.). Problemas conceptuales empíricos. Sagvuntum 30, 135-152.

García Sanjuán, L., Odriozola, C., 2012. La cronología radiocarbónica de la Edad del Bronce (c. 2200-850 cal ANE) en el Suroeste de la Península Ibérica. Anejos de AEspA 62, 363-387.

García Sanjuán, L., Scarre, C., Wheatley, D.W., 2017. The mega-site of Valencina de la Concepción (Seville, Spain): Debating settlement form, monumentality and aggregation in southern Iberian Copper Age societies. J. World Prehist. 30, 239-257.

García-Sanz, C., Fernández-Jurado, J., 1999. La época calcolítica de San Bartolomé de Almonte. Huelva Arqueol. 15, 7-132.

García-Viñas J.I., Mintegui J.A., Robredo J.C., 2005. La vegetación en la marisma del Parque Nacional de Doñana. Organismo Autónomo Parques Nacionales, Ministerio de Medio Ambiente, Madrid.

Garrido, E., Vera, J.C., 2015. Análisis espacial, contextual y funcional de un conjunto de estructuras domésticas del III ${ }^{\text {er }}$ milenio A.C. del yacimiento de "La Orden-Seminario" (Huelva). Revista AtlánticaMediterránea 17, 149-159. 
Gavala, J., 1927. Cádiz y su bahía en el transcurso de los tiempos geológicos. Bol. Inst. Geol. Min. 49, 1-29.

Gavala, J., 1936. Memoria explicativa de la Hoja 1017: El Asperillo, del Mapa Geológico de España, escala 1:50.000. Instituto Geológico y Minero de España, Madrid.

Geertz-Hansen, O., Montes, C., Duarte, M., Sand-Jensen, K., Marbá, N., Grillas, P., 2010. Ecosystem metabolism in a temporary Mediterranean marsh (Doñana National Park, SW Spain). Biogeosciences Discuss. 7, 6495-6521.

Goeury, C., de Beaulieu, J.L., 1979. À propos de la concentration du pollen à l'aide de la liqueur de Thoulet dans les sédiments minéraux. Pollen Spores 21, 239-251.

Gómez-Baggethum, E., Mingorría, S., Reyes-García, V., Calvet, L., Montes, C., 2010. Traditional ecological knowledge trends in the transition to a market economy: empirical study in the Doñana natural areas. Conserv. Biol. 24, 721-729.

Gómez-Baggethum, E., Reyes-García, V., Olsson, P., Montes, C., 2012. Traditional ecological knowledge and community resilience to environmental extremes: A case study in Doñana, SW Spain. Global Environ. Chang. 22, 640-650.

Gómez-Toscano, F., 2006. El final de la Edad de Bronce entre el Guadiana y el Guadalquivir. Síntesis histórico-arqueológica según las más recientes evidencias. Madrid. Mitt. 47, 24-42.

Gómez-Toscano, F., 2008. Cerámicas del Bronce Final en Huelva (1200-600 a.C.). Nueva tipología para explicar su amplitud cronológica. Tabona 16, 85-100.

Gómez-Toscano, F., 2009. Huelva en el año 1000 a.C., un puerto cosmopolita entre el Atlantico y el Mediterráneo. Gerión 27, 33-65.

Gómez-Toscano, F., Campos, J.M., 2008. El Bronce Final prefenicio en Huelva según el registro arqueológico del Cabezo de San Pedro. Una revisión cuarenta años después. Complutum 19, 121-138.

Gómez-Toscano, F., Fundoni, G., 2010-2011. Relaciones del Suroeste con el Mediterráneo en el Bronce Final (siglos XI-X a.C.). Huelva y la isla de Cerdeña. Anales de Arqueología Cordobesa 21-22, 17-56.

Gómez-Toscano, F., Beltrán-Pinzón, J.M., González-Batanero, D., Vera-Rodríguez, J.C., 2014. El Bronce Final en Huelva. Una visión preliminar del poblamiento en su ruedo agrícola a partir del registro arqueológico de La Orden-Seminario. Complutum 25, 139-158.

Grimm, E.C., 1987. Coniss: a Fortran 77 program for stratigraphically constrained cluster analysis by the method of incremental sum of squares. Comput. Geosci. 13, 13-35.

Grimm, E.D., 2004. TGView. Illinois State Museum, Research and Collection Center, Springfield.

Harding, A.E., 2003. Sociedades europeas en la Edad del Bronce. Ariel, Barcelona.

Harrison, R.J., 1985. The 'Policultivo Ganadero', or the secondary products revolution in Spanish agricultura, 5000-1000 BC. Proc. Prehist. Soc. 51, 75-102.

Harrison, R.J., Moreno, G., 1985. El policultivo ganadero o la revolución de los productos secundarios. Trab. Prehist. 42, 51-82. 
Hillbrand, M., Hadorn, P., Cugny, C., Hasenfratz, A., Galop, D., Haas, J.N., 2012. The palaeoecological value of Diporotheca rhizophila ascospores (Dipotothecaceae, Ascomycota) found in Holocene sediments from Lake Nussbaumersee, Switzerland. Rev. Palaeobot. Palynol. 186, 62-68.

Hunt, M., 2003. Prehistoric mining and metallurgy in South West Iberian Peninsula. BAR International Series, Oxford.

Hurtado, V., García Sanjuán, L., Hunt, M.A. (Coords.), 2011. El asentamiento de El Trastejón (Huelva). Investigaciones en el marco de los procesos sociales y culturales de la Edad del Bronce en el suroeste de la Península Ibérica. Junta de Andalucía, Sevilla.

Jalut, G., Dedoubat, J.J., Fontugne, M., Otto, T., 2009. Holocene circum-Mediterranean vegetation changes: climate forcing and human impact. Quat. Int. 200, 4-18.

Jiménez-Moreno, G., Rodríguez-Ramírez, A., Pérez-Asensio, J.N., Carrión, J.S., López-Sáez, J.A., VillaríasRobles, J.J.R., Celestino-Pérez, S., Cerrillo-Cuenca, E., León, Á., Contreras, C., 2015. Impact of lateHolocene aridification trend, climate variability and geodynamic control on the environment from a coastal area in SW Spain. Holocene 25, 607-617.

Lario, J., Zazo, C., Dabrio, C.J., Somoza, L., Goy, J.L., Bardají, T., Silva, P.G., 1995. Record of recent Holocene sediment input on spit bars and deltas of south Spain. J. Coast. Res. Spec. Iss. 17, 241-245.

Lario, J., Luque, L., Zazo, C., Goy, J.L., Spencer, C., Cabero, A., Bardají, T., Borja, F., Dabrio, C.J., Civis, J., González, J.A., Borja, C., Alonso, J., 2010. Tsunami vs. storm surge deposits: a review of the sedimentological and geomorphological records of extreme wave events (EWE) during the Holocene in the Gulf of Cadiz, Spain. Z. Geomorphol. 54, 301-316.

Lario, J., Zazo, C., Goy, J.L., Silva, P.G., Bardají, T., Cabero, A., Dabrio, C.J., 2011. Holocene palaeotsunami catalogue of SW Iberia. Quat. Int. 242, 196-200.

Leblanc, M., Morales, J.A., Borrego, J., Elbaz, F., 2000. 4500 year-old pollution in southwestern Spain: long-term implications for modern mining pollution. Econ. Geol 95, 655-662.

Lillios, K.T., Blanco-González, A., Lee Drake, B., López-Sáez, J.A., 2016. Mid-late Holocene climate, demography, and cultural dynamics in Iberia: A multi-proxy approach. Quat. Sci. Rev. 135, 138-153.

Long, C.J., Whitlock, C., 2002. Fire and vegetation history from the coastal rain forest of the Western Oregon Coast Range. Quat. Res. 58, 215-225.

López-Albacete, I., 2009. La vegetación del manto eólico de Doñana. PhD dissertation, Universidad de Huelva, Huelva.

López-García, P., López-Sáez, J.A., 1994a. Comparison of peats and archaeological samples in the Andalusian region, Spain. In: Davis, O.K. (Ed.), Aspects of archaeological palynology: methodology and applications. American Association of Stratigraphic Palynologists Contributions Series no 29, Houston, pp. $127-139$.

López-García, P., López-Sáez, J.A., 1994b. El paisaje andaluz en la Prehistoria: datos paleopalinológicos. Rev. Esp. Micropal. 26, 49-59. 
López-Sáez, J.A., López-Merino, L., 2005. Precisiones metodológicas acerca de los indicios paleopalinológicos de agricultura en la Prehistoria de la Península Ibérica. Portugalia 26, 53-64.

López-Sáez, J.A., López-Merino, L., 2007. Coprophilous fungi as a source of information of anthropic activities during the Prehistory in the Amblés Valley (Ávila, Spain): the archaeopalynological record. Rev. Esp. Micropal. 39, 103-116.

López-Sáez, J.A., van Geel, B., Farbos-Texier, S., Diot, M.F., 1998. Remarques paléoécologiques à propos de quelques palynomorphes non-polliniques provenant de sédiments quaternaires en France. Rev. Paléobiol. 17, 445-459.

López-Sáez, J.A., López-García, P., Martín-Sánchez, M., 2001. Análisis palinológico del yacimiento arqueológico de Pocito Chico (El Puerto de Santa María): el paisaje prehistórico y protohistórico durante el Holoceno reciente en las Marismas de Cádiz. Cuat. Geomor. 15, 45-59.

López-Sáez, J.A., López-García, P., Martín-Sánchez, M., 2002a. Palaeoecology and Holocene environmental change from a saline lake in South-West Spain: the Protohistorical and Prehistorical vegetation in Cádiz Bay. Quat. Int. 93-94, 197-206.

López-Sáez, J.A., López-García, P., Tixier, C., 2002b. Crisis? What crisis?: 1'anthropisation du milieu et la biodiversité dans la Baie de Cádiz (Espagne). Les apports de la Palynologie. Orsis 17, 91-99.

López-Sáez, J.A., López-García, P., López-Merino, L., Cerrillo, E., González, A., Prada, A., 2005. Prehistoric landscapes in North Extremadura between the $\mathrm{VI}^{\text {th }}$ and the $\mathrm{IV}^{\text {th }}$ millenia cal. BC. J. Iber. Archaeol. 7, 23-35.

López-Sáez, J.A., López-García, P., López-Merino, L., Cerrillo, E., González, A., Prada, A., 2007. Origen prehistórico de la dehesa en Extremadura: Una perspectiva paleoambiental. Rev. Estudios Extrem. 63, 493-509.

López-Sáez, J.A., Alba-Sánchez, F., López-Merino, L., Pérez-Díaz, S., 2010a. Modern pollen analysis: a reliable tool for discriminating Quercus rotundifolia communities in Central Spain. Phytocoenologia 40, $57-72$.

López-Sáez, J.A., López-Merino, L., Alba-Sánchez, F., Pérez-Díaz, S., Abel-Schaad, D., Carrión, J.S., 2010b. Late Holocene ecological history of Pinus pinaster forests in the Sierra de Gredos of central Spain. Plant. Ecol. 206, 195-209.

López-Sáez, J.A., Pérez-Díaz, S., Alba, F., 2011. Antropización y agricultura en el Neolítico de Andalucía Occidental a partir de la Palinología. Menga 2, 72-85.

López-Sáez, J.A., Sánchez-Mata, D., Alba-Sánchez, F., Abel-Schaad, D., Gavilán, R.G., Pérez-Díaz, S., 2013. Discrimination of Scots pine forests in the Iberian Central System (Pinus sylvestris var. iberica) by means of pollen analysis. Phytosociological considerations. Lazaroa 34, 191-208.

López-Sáez, J.A., Abel-Schaad, D., Pérez-Díaz, S., Blanco-González, A., Alba-Sánchez, F., Dorado, M., Ruiz-Zapata, B., Gil-García, M.J., Gómez, C., Franco-Múgica, F., 2014. Vegetation history, climate and human impact in the Spanish Central System over the last 9,000 years. Quat. Int. 353, 98-122. 
López-Sáez, J.A., Alba-Sánchez, F., Sánchez-Mata, D., Abel-Schaad, D., Gavilán, R.G., Pérez-Díaz, S., 2015. A palynological approach to the study of Quercus pyrenaica forest communities in the Spanish Central System. Phytocoenologia 45, 107-124.

López-Sáez, J.A., Abel-Schaad, D., Iriarte, E., Alba-Sánchez, F., Pérez-Díaz, S., Guerra, E., Delibes, G., Abarquero, F.J., 2017. Una perspectiva paleoambiental de la explotación de la sal en las Lagunas de Villafáfila (Tierra de Campos, Zamora). Cuat. Geomor. 31, 73-104.

Magny, M., 1993. Solar influence on Holocene climatic changes illustrated by correlations between past lake-level fluctuations and the atmospheric $14 \mathrm{C}$ record. Quat. Res. 40, 1-9.

Magny, M., 2004. Holocene climate variability as reflected by mid-European lake-level fluctuations and its probable impact on prehistoric human settlements. Quat. Int. 113, 65-79.

Magny, M., Leuzinger, U., Bortenschlager, S., Haas, J.N., 2006. Tripartite climate reversal in Central Europe 5600-5300 years ago. Quat. Res. 65, 3-19.

Martín de la Cruz, J.C., 1994. Avance a la discusión sobre medio ambiente en la Prehistoria. La relación vegetación, fauna en el caso de Papa Uvas (Aljaraque, Huelva). In: Campos, J., Pérez, J.A., Gómez, F. (Eds.), Arqueología en el entorno del Bajo Guadiana. Junta de Andalucía, Huelva, pp. 201-208.

Martín-Consuegra, E., Ubera, J.L., 2011. Informe polínico de los asentamientos de El Trastejón y la Papúa. In: Hurtado, V., García Sanjuán, L., Hunt, M.A. (Coords.), El asentamiento de El Trastejón (Huelva). Investigaciones en el marco de los procesos sociales y culturales de la Edad del Bronce en el suroeste de la Península Ibérica. Junta de Andalucía, Sevilla, pp. 286-301.

Martín-López, B., García-Llorente, M., Palomo, I., Montes, C., 2011. The conservation against development paradigm in protected areas: valuation of ecosystem services in the Doñana socio-ecological system (southwestern Spain). Ecol. Econ. 70, 1481-1491.

Martín-Puertas, C., Jiménez-Espejo, F., Martínez-Ruiz, F., Nieto-Moreno, V., Rodrigo, M., Mata, M.P., Valero-Garcés, B.L., 2010. Late Holocene climate variability in the southwestern Mediterranean region: an integrated marine and terrestrial geochemical approach. Clim. Past 6, 807-816.

Martínez, F., Montero, G., 2004. The Pinus pinea L. woodlands along the coast of South-western Spain: data for a new geobotanical interpretation. Plant Ecol. 175, 1-18.

Mederos, A., 1996. La cronología absoluta de Andalucía Occidental durante la Prehistoria reciente (6100850 A.C.). Spal 5, 45-86.

Medialdea, T., Somoza, L., Pinheiro, L.M., Fernández-Puga, M.C., Vázquez, J.T., León, R., Ivanov, M.K., Magalhaes, V., Díaz-del-Río, V., Vegas, R., 2009. Tectonics and mud volcano development in the Gulf of Cádiz. Mar. Geol. 261, 48-63.

Mellado, D., González, E., Tornos, F., Conde, C., 2006. Geología y estructura de la Mina de Río Tinto (Faja Pirítica Ibérica, España). Geogaceta 40, 231-234.

Menanteau, L., 1981. Les Marismas du Guadalquivir: Exemple de transformation d'un paysage alluvial au cours du Quaternaire récent. PhD dissertation, Université de Paris-Sorbonne, Paris. 
Miyamoto, S., Martínez, I., Padilla, M., Portillo, A., Ornelas, D., 2004. Landscape plant lists for salt tolerance assessment. Agricultural Research and Extension Center of El Paso, Texas Agricultural Experiment Station, Texas A\&M University System, Texas.

Moore, P.D., Webb, J.A., Collinson, M.E., 1991. Pollen analysis. Blackwell, London.

Morales, J.A, Borrego, J.M., San Miguel, E., López-González, N., Carro, B., 2008. Sedimentary record of recent tsunamis in the Huelva Estuary (southwestern Spain). Quat. Sci. Rev. 27, 734-746.

Morales, J.A., Gutiérrez-Mas, J., Borrego, J.M., Rodríguez-Ramírez, A., 2011. Sedimentary characteristics of the Holocene tsunamigenic deposits in the coastal systems of the Cádil Gulf (Spain). In: Mömer, N.A. (Ed.), The tsunami threat: Research and Technology. InTech, London, pp. 237-258.

Morales-Molino, C., Postigo-Mijarra, J.M., García-Antón, M., Zazo, C., 2011. Vegetation and environmental conditions in the Doñana Natural Park coastal area (SW Iberia) at the beginning of the last glacial cycle. Quat. Res. 75, 205-212.

Murillo-Barroso, M., Montero, I., Aranda, G., 2015. An insight into the organisation of metal production in the Argaric society. J. Archaeol. Sci.: Rep. 2, 141-155.

Murillo-Barroso, M., Montero, I., Rafel, N., Hunt, M.A., Armada, X.L., 2016. The macro-regional scale of silver production in Iberia during the first millennium BC in the context of Mediterranean contacts. Oxford J. Archaeol. 35, 75-100.

Nocete, F., 2014. Southern Iberia in the $4^{\text {th }}$ and $3^{\text {th }}$ millennia cal. BC. In: Almagro-Gorbea, M. (Ed.), Iberia. Protohistory of the Far West of Europe: From Neolithic to Roman Conquest. Universidad de Burgos, Burgos, pp. 83-94.

Nocete, F., Álex, E., Nieto, J.M., Sáez, R., Inácio, N., Bayona, M.R., 2004-2005. Intensidad e intensificación en la primera minería y metalurgia del cobre especializada de la Península Ibérica (III milenio ane): la identificación arqueológica de un proceso regional de deforestación y polución. Revista AtlánticaMediterránea 7, 33-49.

Nocete, F., Álex, E., Nieto, J.M., Sáez, R., Bayona, M.R., 2005. An archaeological approach to regional environmental pollution in the south-western Iberian Peninsula related to third millennium BC mining and metallurgy. J. Archaeol. Sci. 32, 1566-1576.

Nocete, F., Queipo, G., Sáez, R., Nieto, J.M., Inácio, N., Bayona, M.R., Peramo, A., Vargas, J.M., CruzAuñón, R., Gil-Ibarguchi, J.I., Santos, J.F., 2008. The smelting quarter of Valencina de la Concepción (Seville, Spain): the specialised copper industry in a political centre of the Guadalquivir valley during the Third Millennium BC (2750-2500 BC). J. Archaeol. Sci. 35, 717-732

Nocete, F., Sáez, R., Bayona, M.R., Péramo, A., Inácio, N., Abril, D., 2011. Direct chronometry $\left({ }^{14}\right.$ C AMS) of the earliest copper metallurgy in the Guadalquivir Basin (Spain) during the Third millennium BC: first regional database. J. Archaeol. Sci. 38, 3278-3295.

Ojeda, J.F., 1990. Doñana Cultural Landscape. In: Doñana, VV.AA. (Eds.), La naturaleza en España. Lunwerg, Barcelona, pp. 18-25. 
Palomo, L., Martín-López, B., Zorrilla, P., Del Amo, D.G., Montes, C., 2014. Deliberative mapping of ecosystem services within and around Doñana National Park (SW Spain) in relation to land use change. Reg. Environ. Change 14, 237-251.

Pals, J.P., van Geel, B., Delfos, A., 1980. Palaeoecological studies in the Klokkeweel bog near Hoogkarspel (Prov. of Noord-Holland). Rev. Palaeobot. Palynol. 30, 371-418.

Pellicer, M., Hurtado, V., 1980. El poblado metalúrgico de Chinflón (Zalamea la Real, Huelva). Universidad de Sevilla, Sevilla.

Pérez-Díaz, S., Ruiz-Fernández, J., López-Sáez, J.A., García-Hernández, C. (Eds.), 2017. Cambio climático y cultural en la Península Ibérica: una perspectiva geohistórica y paleoambiental. Servicio de Publicaciones de la Universidad de Oviedo, Oviedo.

Pérez-Macías, J.A., Campos, J.M., Gómez-Toscano, F., 2002. El poblamiento de la Edad del Cobre en la Tierra Llana de Huelva. Huelva en su Historia 9, 9-34.

Postigo-Mijarra, J.M., Gómez, F., Morla, C., Zazo, C., 2010. Palaeoecological significance of Late Pleistocene pine macrofossils in the lower Guadalquivir Basin (Doñana natural park, southwestern Spain). Palaeogeogr. Paeoclimatol. Palaeoecol. 295, 332-343.

Prentice, L.C., 1985. Pollen representation, source area, and basin size: towards a unified theory of pollen analysis. Quat. Res. 23, 76-86.

Reed, J.M., Stevenson, A.C., Juggins, S., 2001. A multi-proxy record of Holocene climatic change in southwestern Spain: the Laguna de Medina, Cádiz. Holocene 16, 707-719.

Reille, M., 1999. Pollen et spores d'Europe et d'Afrique du Nord, $2^{\text {nd }}$ edn. Laboratoire de Botanique Historique et Palynologie, Marseille.

Reimer, P.J., Bard, E., Bayliss, A., Beck, J.W., Blackwell, P.G., Bronk Ramsey, C., Buck, C.E., Cheng, H., Edwards, R.L., Friedrich, M., Grootes, P.M., Guilderson, T.P., Haflidason, H., Hajdas, I., Hatté, C., Heaton, T.J., Hoffmann, D.L., Hogg, A.G., Hughen, K.A., Kaiser, K.F., Kromer, B., Manning, S.W., Niu, M., Reimer, R.W., Richards, D.A., Scott, E.M., Southon, J.R., Staff, R.A., Turney, C.S.M., van der Plicht, J., 2013. Intcal13 and marine13 radiocarbon age calibration curves 0-50,000 years cal BP. Radiocarbon 55, 1869-1887.

Rivas-Martínez, S., Costa, M., Castroviejo, S., Valdés, E., 1980. Vegetación de Doñana (Huelva, España). Lazaroa 2, 5-189.

Rodríguez-Ramírez, A., 1998. Geomorfología del Parque Nacional de Doñana y su entorno. Organismo Autónomo Parques Nacionales, Ministerio de Medio Ambiente, Madrid.

Rodríguez-Ramírez, A., Yáñez, C., 2008. Formation of chenier plain of the Doñana marshland (SW Spain): observations and geomorphic model. Mar. Geol. 254, 187-196.

Rodríguez-Ramírez, A., Rodríguez-Vidal, J., Cáceres, L., Clemente, L., Belluomini, G., Manfra, L., Improta, S., de Andrés, J.R., 1996. Recent coastal evolution of the Doñana National Park (SW Spain). Quat. Sci. Rev. 15, 803-809. 
Rodríguez-Ramírez, A., Cáceres, L., Rodríguez-Vidal, J., 2005. Geomorphology of the Doñana National Park. In: Desir, G., Gutiérrez, F., Gutiérrez, M. (Eds.), Sixth International Conference on Geomorphology, field trip guides, S.E.G., Zaragoza, pp. 388-396.

Rodríguez-Ramírez, A., Jiménez-Moreno, G., Pérez-Asensio, J.N., Contreras, C., Morales, J.A., 2012. Formaciones de turba durante el Holoceno reciente en el P.N. de Doñana (SW, España): Implicaciones Ambientales. In: González-Díez, A (Coord.), Avances de la Geomorfología en España 2010-2012. XII Reunión Nacional de Geomorfología. Universidad de Cantabria, Santander, pp. 347-350.

Rodríguez-Ramírez, A., Flores-Hurtado, E., Contreras, C., Villarías-Robles, J.J.R., Jiménez-Moreno, G., Pérez-Asensio, J.N., López-Sáez, J.A., Celestino-Pérez, S., Cerrillo-Cuenca, E., León, Á., 2014. The role of neo-tectonics in the sedimentary infilling and geomorphological evolution of the Guadalquivir estuary (Gulf of Cádiz, SW Spain) during the Holocene. Geomorphology 219, 126-140.

Rodríguez-Ramírez, A., Pérez-Asensio, J.N., Santos, A., Jiménez-Moreno, G., Villarías-Robles, J.J.R., Mayoral, E., Celestino-Pérez, S., Cerrillo-Cuenca, E., López-Sáez, J.A., León, Á., Contreras, C., 2015. Atlantic extreme wave events during the last four millennia in the Guadalquivir estuary, SW Spain. Quat. Res. 83, 24-40.

Rodríguez-Ramírez, A., Villarías-Robles, J.J.R., Pérez-Asensio, J.N., Santos, A., Morales, J.A., CelestinoPérez, S., León, Á., Santos-Arévalo, F.J., 2016. Geomorphological record of extreme wave events during Roman times in the Guadalquivir estuary (Gulf of Cadiz, SW Spain): An archaeological and paleogeographical approach. Geomorphology 261, 103-118.

Rothenberg, B., Blanco, A., 1980. Ancient copper mining and smelting at Chinflón (Huelva, SW Spain). In:

Craddock, P.T. (Ed.), Scientific studies in early mining and extractives metallurgy. British Museum Occasional Paper 20, London, pp. 41-62.

Ruiz, F., González-Regalado, M.L., Pendón, J.G., Abad, M., Olías, M., Muñoz, J.M., 2005a. Correlation between foraminifera and sedimentary environments in recent estuaries of southwestern Spain: applications to Holocene reconstructions. Quat. Int. 140-141, 21-36.

Ruiz, F., Rodríguez-Ramírez, A., Cáceres, L.M., Rodríguez-Vidal, J., Carretero, M.I., Abad, M., Olías, M., Pozo, M., 2005b. Evidence of high-energy events in the geological record: Mid-Holocene evolution of the southwestern Doñana National Park (SW Spain). Palaeogeogr. Paeoclimatol. Palaeoecol. 229, 212-229.

Ruiz, F., Pozo, M., Carretero, M.I., Abad, M., González-Regalado, M.L., Muñoz, J.M., Rodríguez-Vidal, J., Cáceres, L.M., Pendón, J.G., Prudêncio, M.I., Dias, M.I., 2010. Birth, evolution and death of a lagoon: Late Pleistocene to Holocene palaeoenvironmental reconstruction of the Doñana National Park (SW Spain). In: Friedman, A.G. (Ed.), Lagoons: Biology, management and environmental impact. Nova Science Publishers, Hauppauge, pp. 371-398.

Ruiz-Gálvez, M.L. (Ed.), 1995a. Ritos de paso y puntos de paso: la Ría de Huelva en el mundo del Bronce Final Europeo. Universidad Complutense, Madrid. 
Ruiz-Gálvez, M.L., 1995b. Cronología de la Ría de Huelva en el marco del Bronce Final de Europa occidental. In: Ruiz-Gálvez, M.L. (Ed.), Ritos de paso y puntos de paso: la Ría de Huelva en el mundo del Bronce Final Europeo. Universidad Complutense, Madrid, pp. 79-83.

Ruiz-Gálvez, M., 2013. Con el fenicio en los talones. Los inicios de la Edad del Hierro en la cuenca de Mediterráneo. Bellaterra, Barcelona.

Ruiz-Gil, J.A., López-Amador, J.J., 2001. Formaciones sociales agropecuarias en la Bahía de Cádiz, 5000 años de adaptación ecológica en la Laguna del Gallo (El Puerto de Santa María). Arqueodesarrollo Gaditano, Sanlúcar de Barrameda.

Ruiz-Mata, D., Gómez-Toscano, F., 2008. El final de la Edad del Bronce en el suroeste ibérico y los inicios de la colonización fenicia en occidente. In: Celestino-Pérez, S., Rafel, N., Armada, X.L. (Eds.), Contacto cultural entre el Mediterráneo y el Atlántico (siglos XII-VIII ane). La precolonización a debate. CSIC, Madrid, pp. 323-353.

Sáenz, C., 1979. Pollen morphology of Spanish Cistaceae. Grana 18, 91-98.

Sáenz, C., 1982. Polen de la flora de Doñana (Huelva, España). Lazaroa 2, 191-270.

Schneider, H., Höfer, D., Trog, C., Mäusbacher, R., 2016. Holocene landscape development along the Portuguese Algarve coast: A high resolution palynological approach. Quat. Int. 407, 47-63.

Schulten, A., 1945. Tartessos. Colección Austral, Espasa Calpe, Madrid.

Serrano, L., Reina, M., Martín, G., Reyes, I., Arechederra, A., León, D., Toja, J., 2006. The aquatic systems of Doñana (SW Spain): watersheds and frontiers. Limnetica 25, 11-32.

Sherrat, A.G., 1981. Plough and pastoralism: aspects of the secondary products revolution. In: Hodder, I. (Ed.), Pattern of the past. Cambridge University Press, Cambridge, pp. 261-305.

Siljeström, P.A., Clemente, L.E., 1990. Geomorphology and soil evolution of a moving dune system in SW Spain (Doñana National Park). J. Arid. Environ.18, 139-150.

Siljeström, P.A., Moreno, A., García, L.V., Clemente, L.E., 1994. Doñana National Park (south-west Spain) : geomorphological characterization through a soil-vegetation study. J. Arid. Environ. 26, 315-323.

Soares, A.M., Martins, J.M., 2010. Radiocarbon dating of marine samples from Gulf of Cadiz: The reservoir effect. Quat. Int. 221, 9-12.

Stevenson, A.C., 1984. Studies in the vegetational history of S.W. Spain. III. Palynological investigations at El Asperillo, Huelva. J. Biogeogr. 11, 527-551.

Stevenson, A.C., 1985. Studies in the vegetational history of S.W. Spain. II. Palynological investigations at Laguna de las Madres, Huelva. J. Biogeogr. 12, 293-314.

Stevenson, A.C., Harrison, R., 1992. Ancient forest in Spain: a model for land use and dry forest management in South-West Spain from 4000 BC to 1900 AD. Proc. Prehist.Soc. 58, 227-247.

Stevenson, A.C., Moore, P.D., 1988. Studies in the vegetational history of S.W. Spain. IV. Palynological investigations of a valley mire at El Acebron. Huelva. J. Biogeogr. 15, 339-361.

Stockmarr, J., 1971. Tablets with spores used in absolute pollen analysis. Pollen Spores 13, 614-621. 
Suárez, J., Márquez, J.E., 2014. La problemática de los fondos de cabaña en el marco de la arquitectura protohistórica del sur de la Península Ibérica. Menga 5, 199-225.

Tejera-Gaspar, A., 1985. Excavaciones arqueológicas en el Huerto Pimentel (Lebrija, Sevilla). Noticiario Arqueológico Hispánico 26, 88-116.

Tornos, F., 2008. La geología y la metalogenia de la Faja Pirítica Ibérica. Macla 10, 13-23.

Torres-Ortiz, M. 2002. Tartessos. Real Academia de la Historia, Madrid.

Valdés, B., Girón, V., Sánchez, E., Carmona, I., 2007. Catálogo florístico del espacio natural de Doñana (SO de España). Plantas vasculares. Lagascalia 27, 73-362.

van Geel, B., 2001. Non-pollen palynomorphs. In: Smol, J.P., Birks, H.J.B., Last, W.M. (Eds.), Tracking environmental change using lake sediments, vol. 3, Terrestrial, algal, and siliceous indicators. Kluwer, Dordrecht, pp 99-119.

van Geel, B., Aptroot, A., 2006. Fossil ascomycetes in Quaternary deposits. Nova Hedwigia 82, 313-329.

van Geel, B., Coope, G.R., van der Hammen, T., 1989. Palaeoecology and stratigraphy of the Late-glacial type section al Usselo (The Netherlands). Rev. Palaeobot. Palynol. 60, 25-129.

van Geel, B., Mur, L.R., Ralska-Jasiewiczowa, M., Goslar, T., 1994. Fossil akinetes of Aphanizomenon and Anabaena as indicators for medieval phosphate-eutrophication of Lake Gosciaz (Central Poland). Rev. Palaeobot. Palynol. 83, 97-105.

van Geel, B., Odgaard, V., Ralska-Jasiewiczowa, M., 1996. Cyanobacteria as indicators of phosphateeutrophication of lakes and pools in the past. Pact 50, 399-415.

Vannière, B., Colombaroli, D., Chapron, E., Leroux, A., Tinner, W., Magny, M., 2008. Climate versus human-driven fire regimes in Mediterranean landscapes: the Holocene record of Lago dell'Accesa (Tuscany, Italy). Quat. Sci. Rev. 27, 1181-1196.

Vera, J.C., Echevarría, A., 2013. Sistemas agrícolas del I milenio a.C. en el yacimiento de La OrdenSeminario de Huelva. Viticultura protohistórica a partir del análisis arqueológico de las huellas de cultivo. In: Celestino, S., Blánquez, J. (Eds.), Patrimonio cultural de la vid y el vino. CSIC, Madrid, pp. 95-106.

Whitlock, C., Larsen, C., 2001. Charcoal as a fire proxy. In: Smol, J.P., Birks, H.J.B., Last, W.M. (Eds.), Tracking environmental change using lake sediments, vol. 3, Terrestrial, algal, and siliceous indicators. Kluwer, Dordrecht, pp. 75-97.

Yin, Y., Liu, H., Hao, Q., 2016. The role of fire in the late Holocene forest decline in semi-arid North China. Holocene 26, 93-101.

Yll, R., Zazo, C., Goy, J.L., Pérez, R., Pantaleón, J., Civis, J., Dabrio, C., González, A., Borja, B., Soler, V., Lario, J., Luque, L., Sierro, F., González, F.M., Lezine, A.M., Denèfle, M., Roure, J.M., 2003. Quaternary palaeoenvironmental changes in South Spain. In: Ruiz-Zapata, B., Dorado, M., Valdeolmillos, A., Gil, M.J., Bardají, T., Bustamante, I., Martínez, I. (Eds.), Quaternary climatic changes and environmental crises in the Mediterranean region. Universidad de Alcalá -INQUA, Alcalá de Henares, pp. 201-213. 
Zazo, C., Goy, J.L., Somoza, L., Dabrio, C.J., Belluomini, G., Improta, S., Lario, J., Bardaji, T., Silva, P.G., 1994. Holocene sequence of sea-level fluctuations in relation to climatic trends in the AtlanticMediterranean linkage coast. J. Coast. Res. 10, 933-945.

Zazo, C., Lezine, A.M., Borja, F., Denèfle, M., Dabrio, C.J., Lario, J., Rodríguez-Vidal, J.,Goy, J.L., Bardají, T., Díaz del Olmo, F., Cáceres, L., Clemente, L., Baeteman, C., Rodríguez-Ramírez, A., 1996. Holocene coastal progradation changes and peat bog development in SW Spanish coast. In: Zazo, C., Bardají, T. (Eds.), Subcommission on Mediterranean and Black Sea shorelines. INQUA, Madrid, pp. 13-17. 
Table 1. AMS-radiocarbon data with $2 \sigma$ range of calibration from S1 core.

\begin{tabular}{llllll}
\hline Laboratory code & Depth $(\mathrm{cm})$ & ${ }^{14} \mathrm{C}$ age BP & Age cal BP & Median & $\Delta \mathrm{R}\left({ }^{14} \mathrm{C}\right.$ yr $)$ \\
\hline D-AMS 006934 & 200 & $3053 \pm 22$ & $2966-2416$ & 2721 & $100 \pm 100$ \\
\hline D-AMS 006935 & 360 & $3153 \pm 29$ & $3136-2606$ & 2842 & $100 \pm 100$ \\
\hline Beta-288897 & 580 & $3560 \pm 40$ & $3598-3048$ & 3331 & $100 \pm 100$ \\
\hline D-AMS 006936 & 850 & $4286 \pm 30$ & $4544-3962$ & 4266 & $100 \pm 100$ \\
\hline Beta-288898 & 1000 & $4560 \pm 40$ & $4891-4347$ & 4636 & $100 \pm 100$ \\
\hline
\end{tabular}




\section{FIGURES}

Fig. 1. Study area and location of the S1 core. (a) Geomorphological units of the Doñana National Park. (b) Vegetation map of the Doñana National Park. Wind directions are also indicated.

Fig. 2. Granulometry, bio-sedimentary units, calibrated ages (cal BP), and cultural periods of the S1 core.

Fig. 3. Percentage pollen diagram of the S1 core (woodland vegetation) plotted against age (cal BP). The black silhouettes show the percentage curves of the taxa, the grey silhouettes show the $\mathrm{x} 5$ exaggeration curves. Groups of pollen were established according to their ecological affinities, following Galiano and Cabezudo (1976) and RivasMartínez et al. (1980).

Fig. 4. Percentage pollen diagram of the S1 core (herbs, hydro-hygrophytic taxa, ferns and non-pollen palynomorphs) plotted against age (cal BP). The black silhouettes show the percentage curves of the taxa, the grey silhouettes show the x5 exaggeration curves. Groups of pollen and non-pollen palynomorphs were established according to their ecological affinities, following Galiano and Cabezudo (1976), Rivas-Martínez et al. (1980), van Geel (2001) and López-Albacete (2009).

Fig. 5. Cultural periods, EWEs, climatic events, percentage pollen diagram (selected pollen and NPP taxa), and charcoal accumulation rates (CHARs) plotted against age (cal BP) from the S1 core.

Fig. 6. (a) Geographic framework of the study area: southwestern Iberian Peninsula. (b) Main Chalcolithic (white circles) and Early Bronze Age archaeological sites (blue circles) on the southwestern Iberian corner. Dotted white line represents the hypothetical position of the Guadalquivir paleoestuary (Arteaga et al., 2016) and the black rectangle the study area (Doñana National Park). Location of the S1 core (white star) and geomorphological scenario of the study area (c) 5000-4200 and (d) 4200-3500 cal BP, respectively, following Rodríguez-Ramírez et al. (2014, 2015). Palaoenvironmental records mentioned in the text: AC (El Acebrón), AS (Asperillo), BE (Beliche), CJ (Cabezo Juré), JR (La Junta de los Ríos), MA (Las Madres), ME (Medina Lake), ML (Marilópez), MR (Marismillas), OT (Odiel-Tinto estuary core), PC (Pocito Chico), PN (PN core), PP (Papúa II), S7 (S7core), S9 (S9 core), S11 (S11 core), TT (El Trastejón), VC (Valencina de la Concepción).

Fig. 7. (a) Nuclear areas of pre-Phoenician Late Bronze Age ( 3200-2800 cal BP) archaeological sites in the southwest of the Iberian Peninsula (modified from Gómez-Toscano, 2008). Dotted white line represents the hypothetical position of the Guadalquivir paleoestuary (Arteaga et al., 2016) and the black rectangle the study area (Doñana National Park). Location of the S1 core (white star) and geomorphological scenario of the study area (b) 3500-3435, (c) 3185-3140 and (d) 3140-2800 cal BP, respectively, following Rodríguez-Ramírez et al. (2014, 2015). Palaoenvironmental records mentioned in the text: S7 (S7 core), S11 (S11 core). 


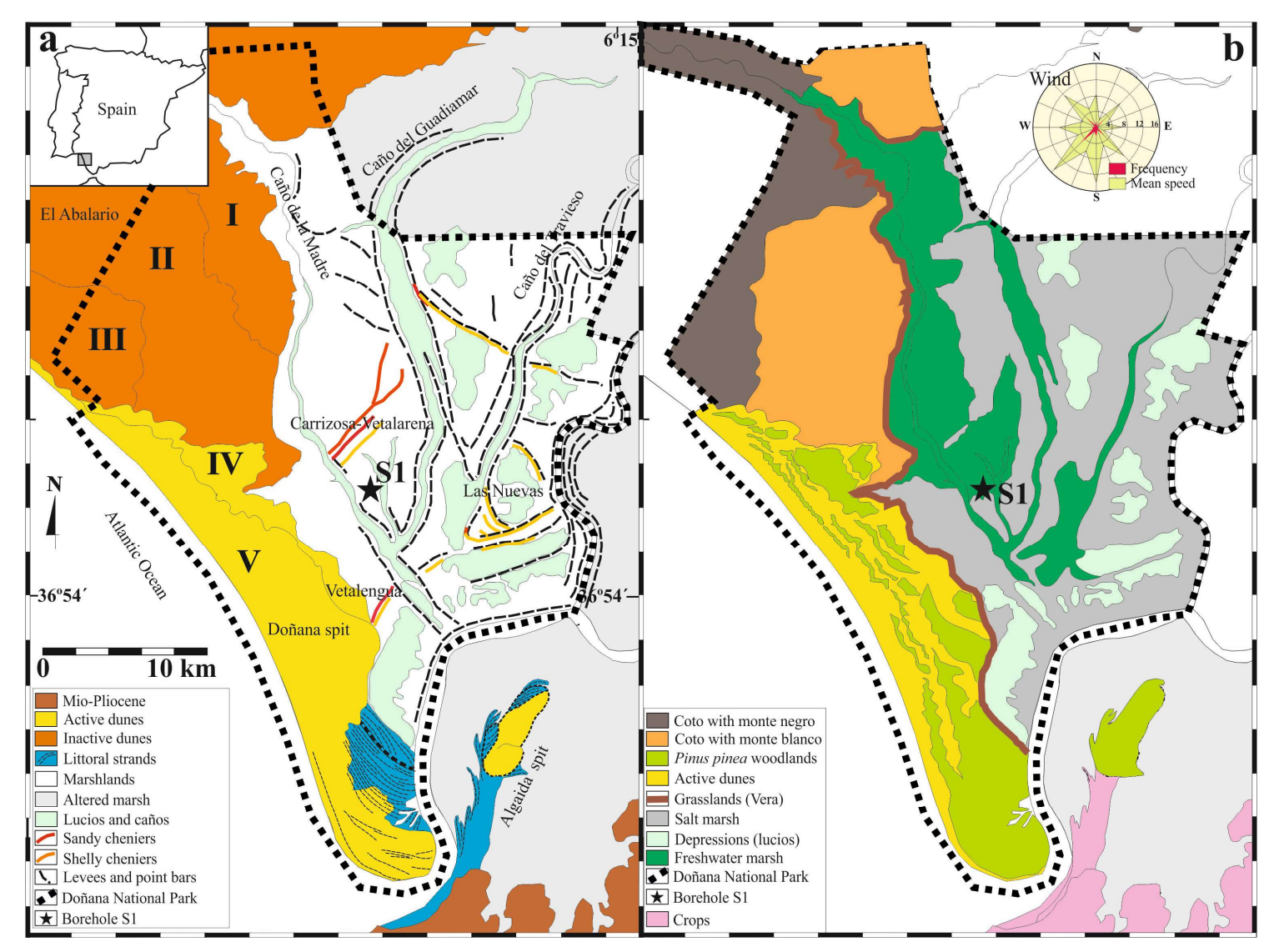

Fig. 1 


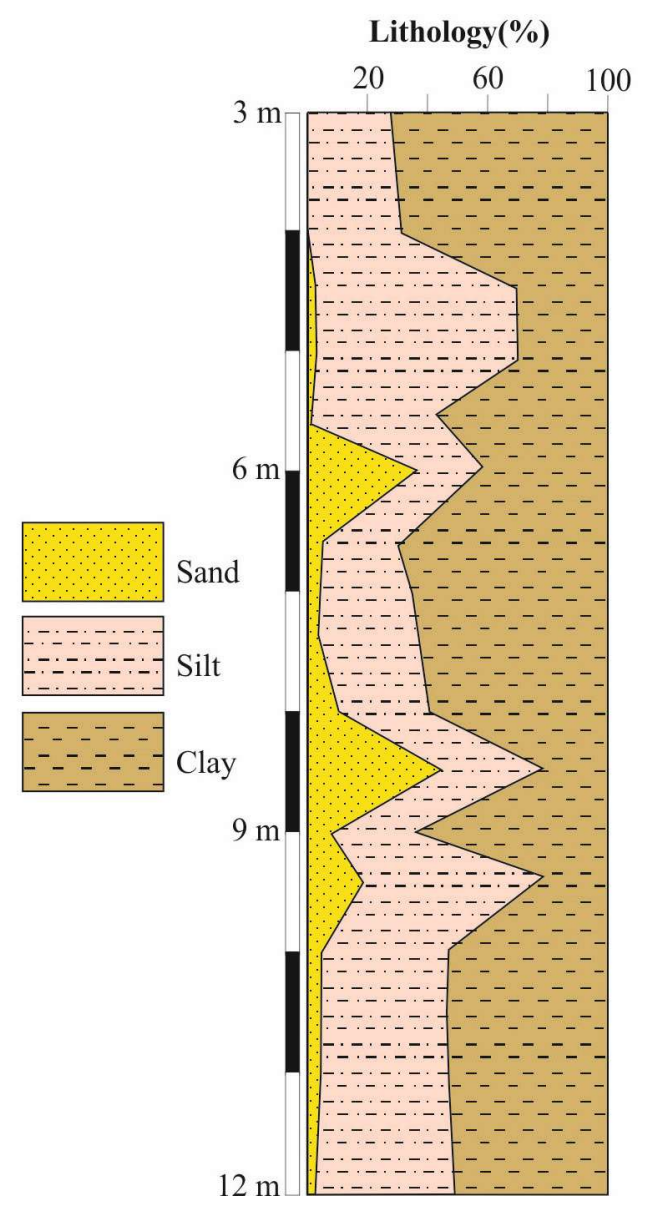

Fig. 2 


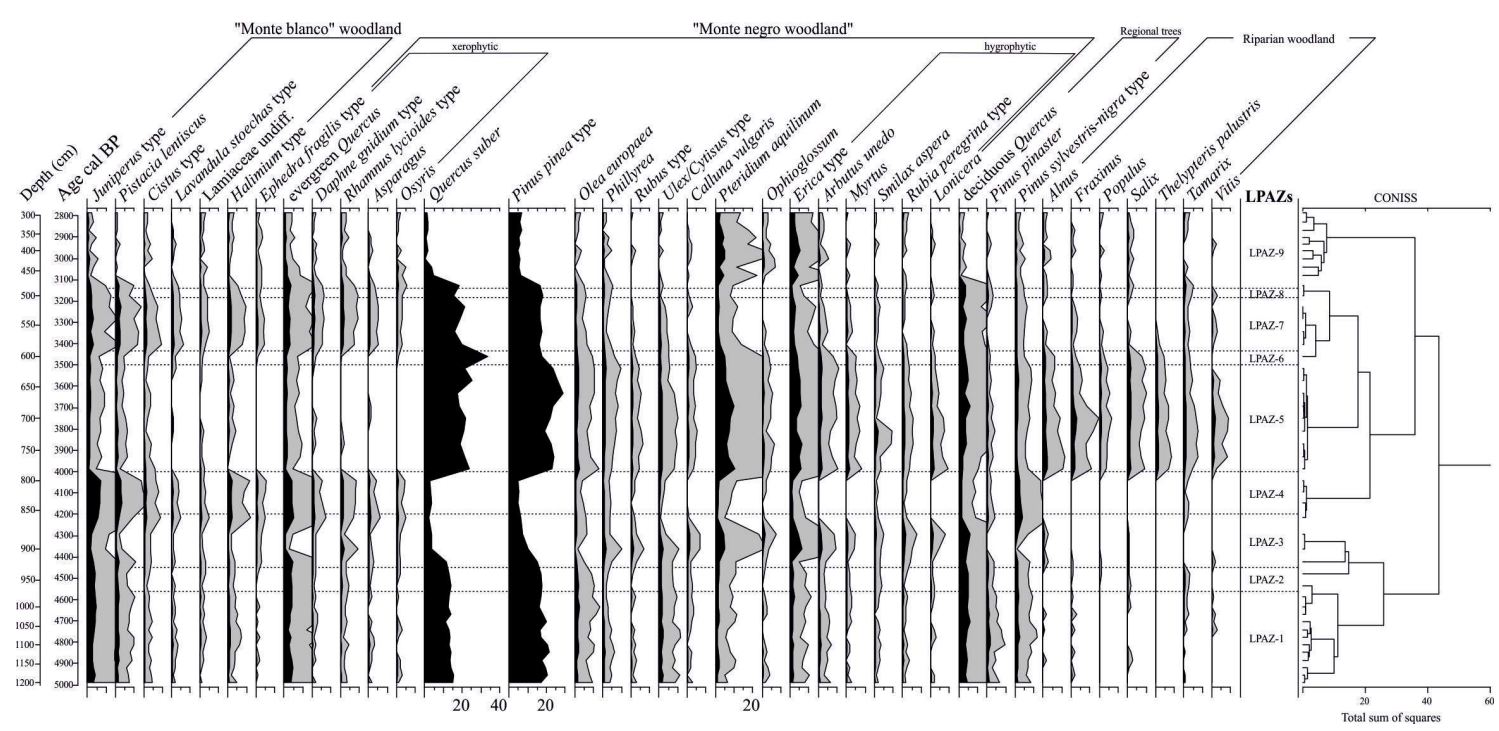

Fig. 3 


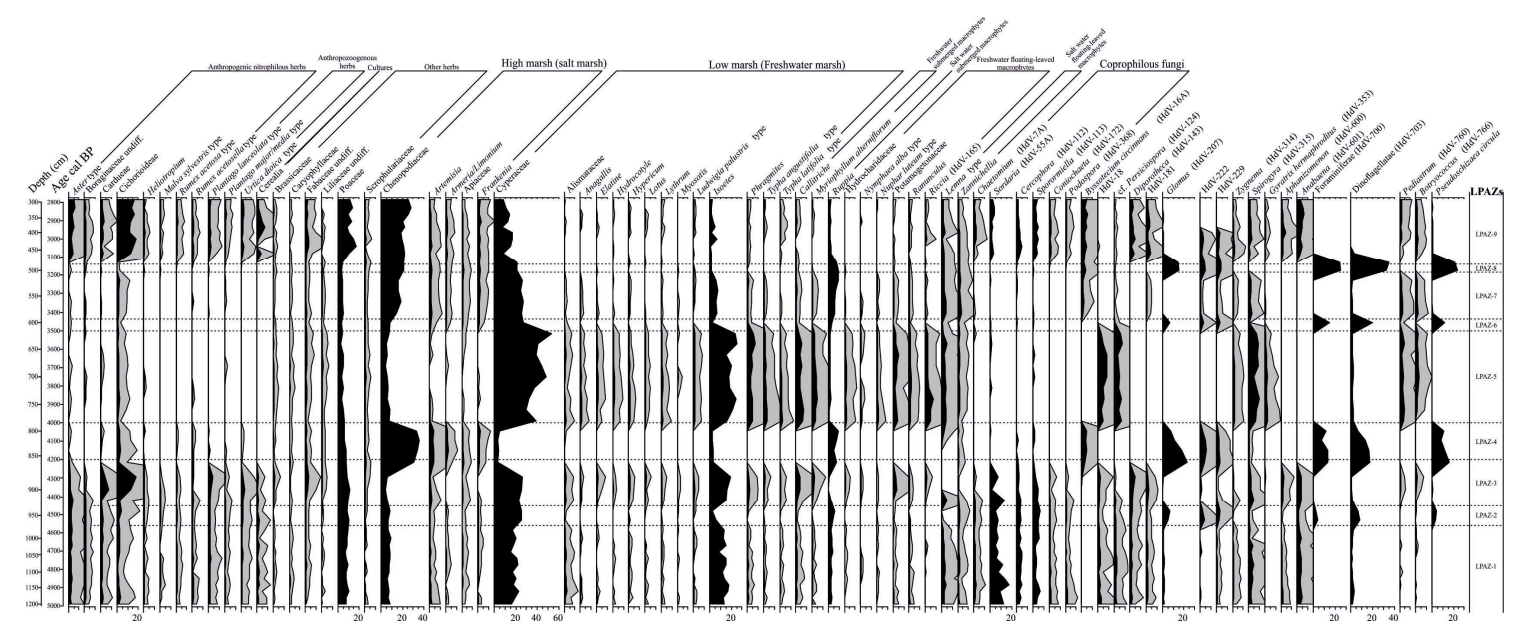

Fig. 4 


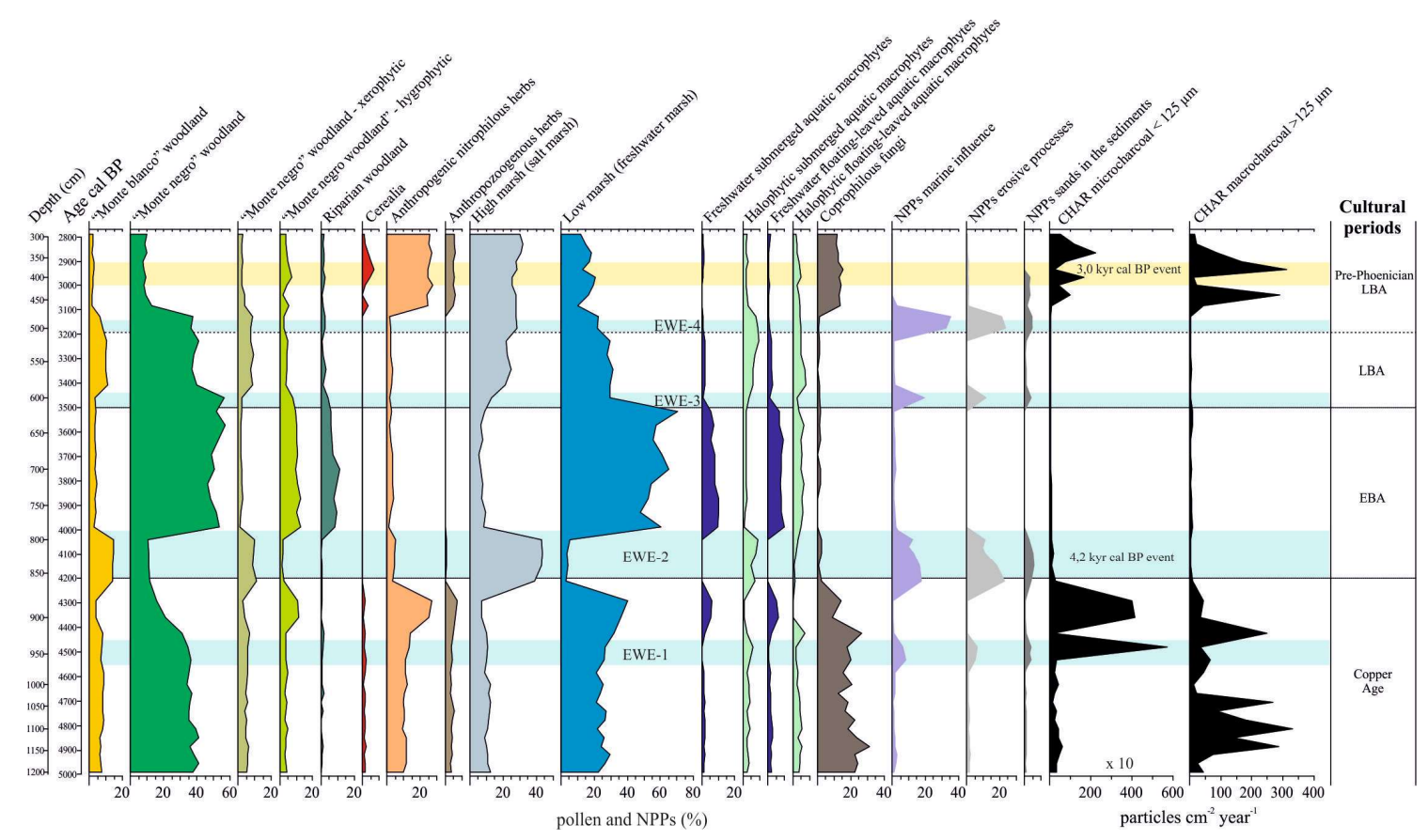

Fig. 5 


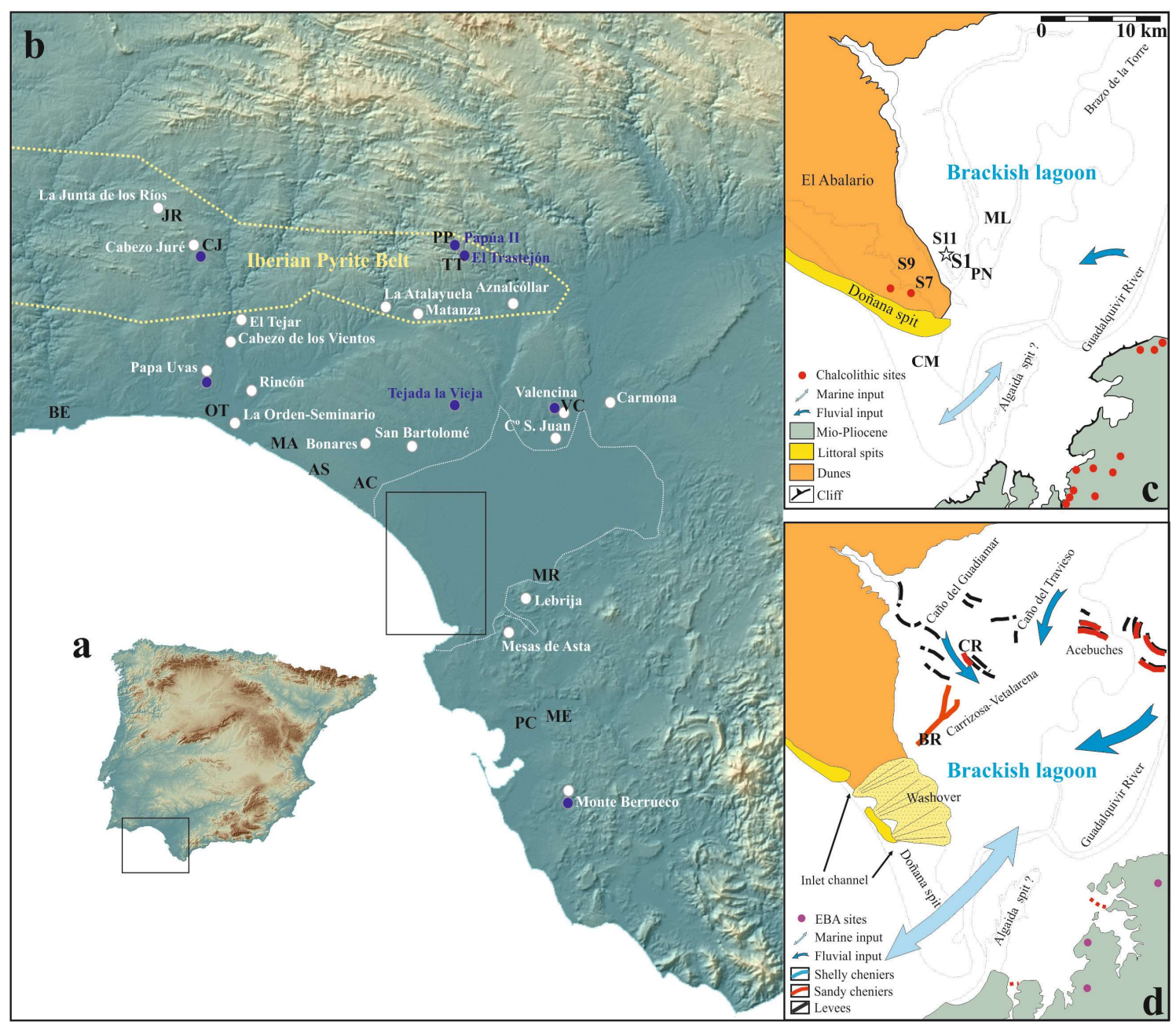

Fig. 6 


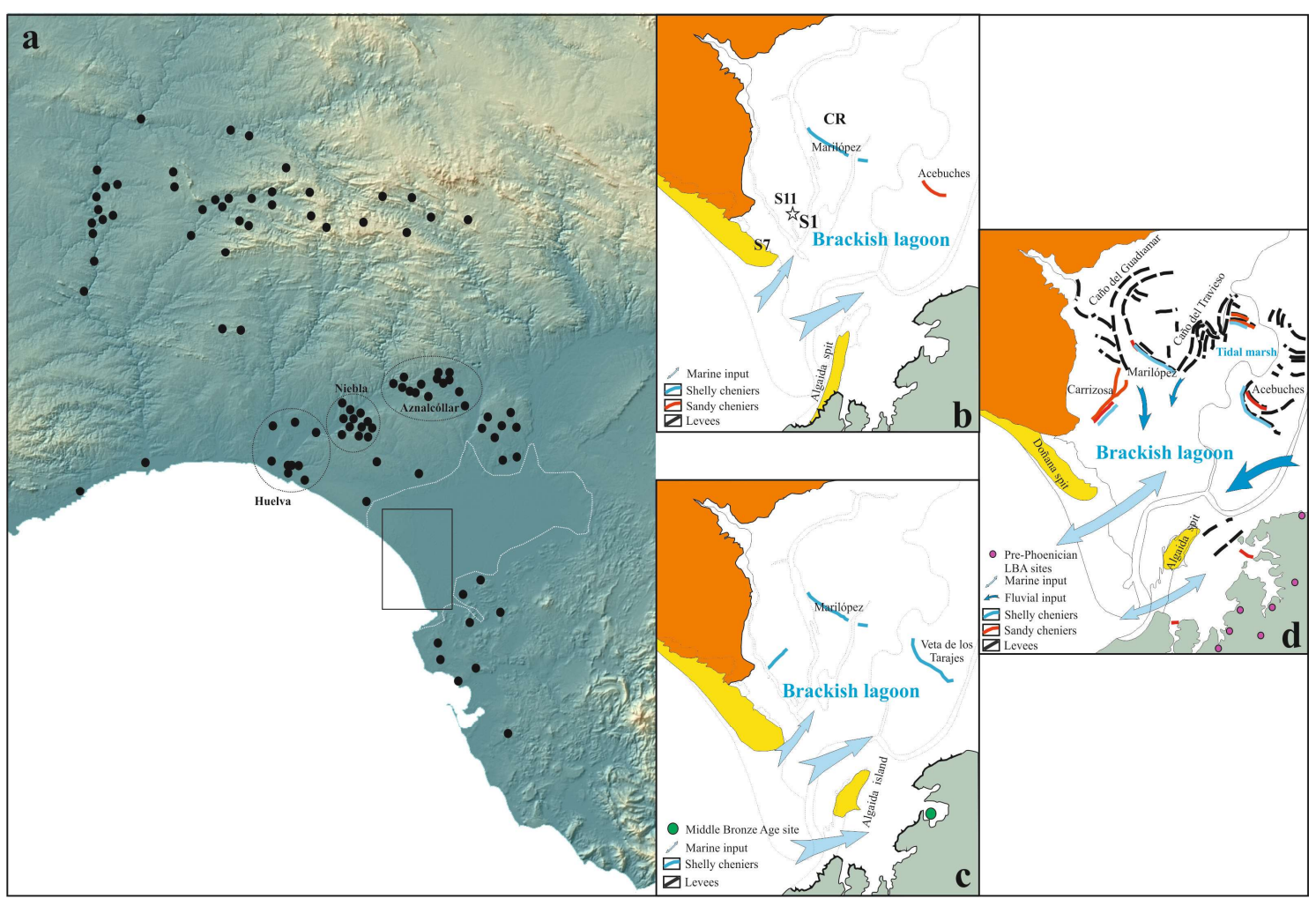

Fig. 7 